\title{
أشكال التعبير عن دلالات الفقد والتشظي عند المرأة
}

\section{القصة العراقية القصيرة انموذجاً}

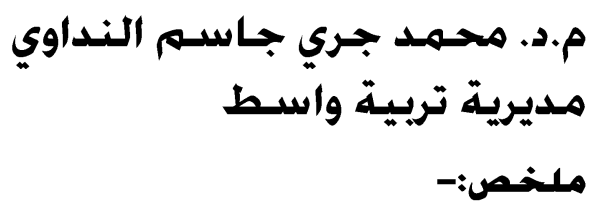

أكتسب التثظي والفقد عند الكاتبات العراقيات مفهوماً أكثر عمقاً واتسـاعاً، وقد تجسد ذلك بوضوح في كتابـاتهن بشكل لافت، لاسبما القصصية منها، إذ رسمت المتون السردية للقصص عينة البحث تثظي شخصياتها في العالم المتخيل وتأزم محنتهن. وقد عبرت الكاتبات

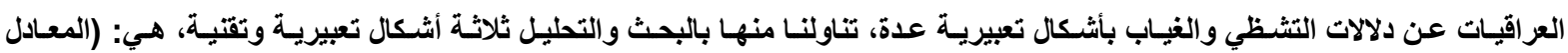

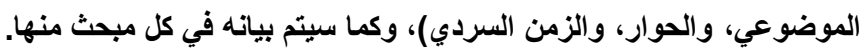

\section{Abstract}

The fragmentation and loss of Iraqi female writers gained deep understanding. This was reflected in their writings in a clear and especially descriptive manner. The narrative texts of the stories were drawn from the sample, the dispersion of the characters in the imaginary world, and the reality of the characters.

The Iraqi writers have expressed the signs of fragmentation and loss in many forms of expression, from which we dealt with research and analysis three forms of expression and technique, namely: (the substantive equivalent, dialogue and narrative time), as will be explained in each section.

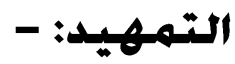

أكتسب التشظي و الفقد*عند الكاتبات العر اقبـات مفهومـاً أكثر عمقاً و اتسـاعاً، وقد تجسـ ذلك بوضـوح في

كتابـاتهن بشـكل لافـت، لاسـيما القصصـية منهـا، إذ رسـمت المتـون السـردية للقصـص عينـة البحـث تشـظي شخصياتها في العالم المتخيل وتأزم محنتهن، وقد يكون لذلك تماهيـا مـع الحيـاة الو اقعيـة للمبدعـة العر اقيـة، ذلك أن الأديب لا يكتب من فر اغ، إذ لا بد أن يكون متأثراً بالمحيط الذي يحويه ويتفاعل فيه ومعـه، كمـا أن مـا يكتبه قد يكون متأثراً أيضناً باسقاطات تأزماتـه أو انكسـار اته على المستوى الثخصـي الذاتي، أو حتى المستوى العـام عندما يتشكل هنالك و عي جمعي يترك الأديب متأثراً ومؤثراً في و اقعه، ومتطلعاً إلى خلق واقع جديد، أو على الأقل، التفاعل مع الو اقع المعيش بكل سلبياته أو تتاقضاته التي تترك الذات تعاني انكسـار ها أو تشظيها، وسـأمها من لا جدواها إن هي أخفقت في انتاج واقع يكفل لها اندماجها فيه وتماهيها معـه، وشـور ها تجاهـه بالرضـى و القبول، ولا أربد أن أقول هنا أن المتون السردية ما هي إلا تجسيد للواقع فحسب، لكنها فوق ذلك تحدد موقفاً منها(')؛ لأنها في كثير من الأحيان تكون قادرة على رصد وضع الواقع المعيش من خلال مـا تُجسِّده شخصياتها من أدوار(r)، فتصير النصوص السردية على أساس ذلك، طاقة سياسية واجتماعيـة وثقافية ذات بعد إيديولوجي له ارتهاناته التي تبرز في النص السـردي، وتحـاكم أحياناً الو اقع، من خـلال مـا ترسمه الثخصيات من صـور ومعانٍ أو أدوار، وأن هذا البعد الإيديولوجي يتداخل فيه الانفعـلي، فينتج عن تداخلهما قطعة فنيـة ذات إحسـاس

$$
\text { مر هف مشحون بالعاطفة. }
$$


إن سمة الانكسار والحزن والاحساس بالفقد تكاد تكون ظـاهرة ملفتـة للنظر في أكثر الفنون الأدبيـة إن لم

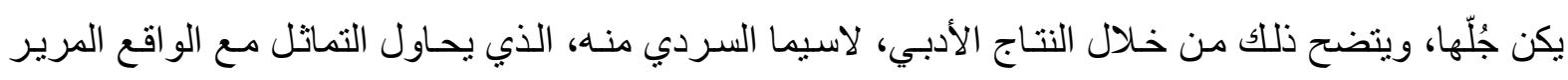

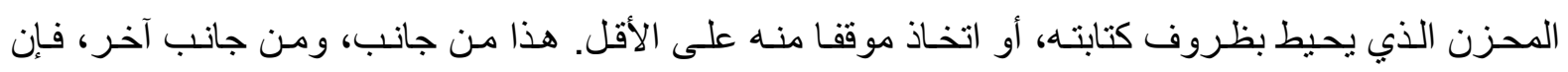
الإلحاح على إبراز هذا الجانب المعتم والمحزن في النصوص السردية، وخلق عالم أسود لشخصيات متشظية أو هن

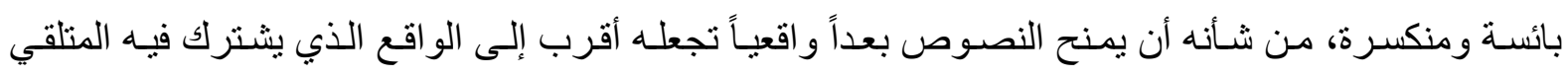
و المؤلف، فتكون تلك النصوص أقرب إلى التصديق، ممـا يسمح بالتفاعل مـع هذه النصـوص، ويمنحها بعداً جمالياً جر اء ذلك.

إز اء كل ما تقدم، تتجلى لنا حقيقة لا بد من تأكيدها، وهي أن ((الرؤية الحسية ذات وجه واحد؛ فأنت حين

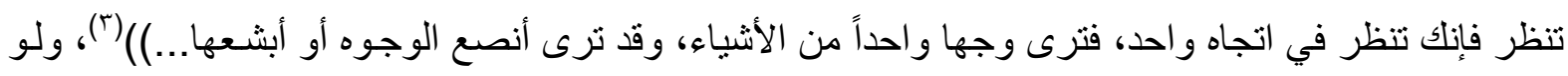

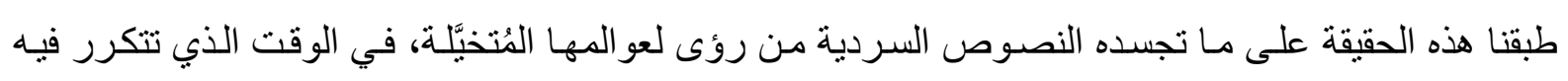
الرؤية للأشياء البشعة أو للو اقع البشع؛ بسبب كثرة تواردها للمشاهدة فيها، فإن ذلك يولد إدر اكاً شتعورياً جديداً

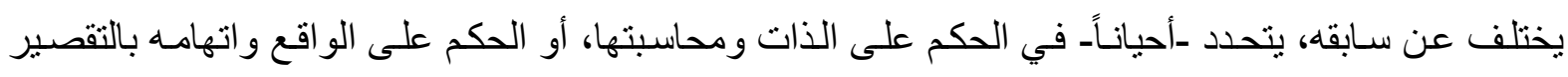
والسلبية، وهو ما ستفصح عنه مباحث هذا البحث بعون الله وتوفيقه. كمـا لابـ من الإشـارة إلى أن العينـة التي

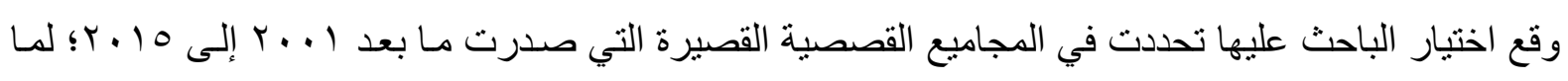

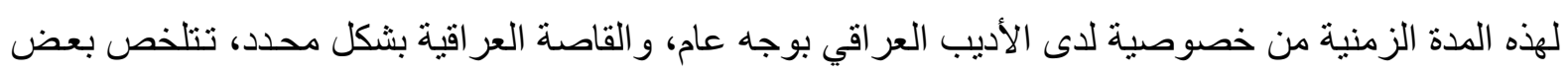
مفاصل تلك الخصوصية في الوعي الفني بالقصـة القصيرة، و القدرة على التفنن في نتكيل نصوصهـا ومتونها السردية، و المهارة الواضحة في توظيف تقنياتها، فضـلاً عمَّا اتسمت بـه هذه المدة من اضطر ابات على جميع المستويات في البيئة التي كتبت بها هذه النصوص، بدءاً من اختلال التوازنـات الدولية على اثر السياسـة التي في

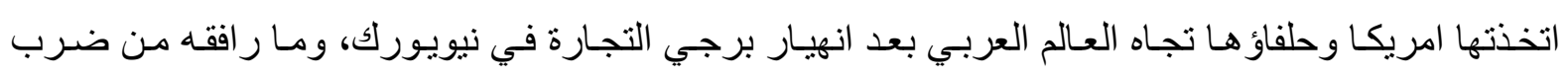

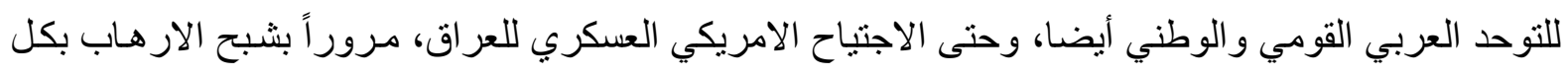

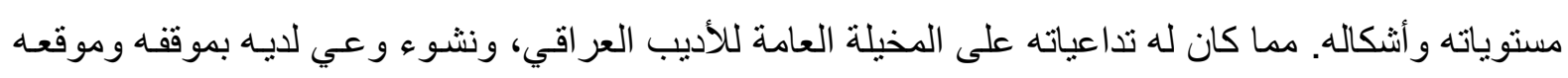
تجاه كل ذللك، و هو ما سيتم الاشارة إليه في مباحث هذه الدراسة، وذللك بحسب أهميته لموضو عها.

\section{المبسحث الأول- المعادل الموضهوعي}

منذ أن نشر إيليوت مقالته النقديـة "Hamlet and problems" هاملت ومشكلاته عـام 919 متحى حتى

اكتسب مصطلح المعادل الموضو عي اهتماماً كبيراً من قبل النقاد والمبدعين الذين تلققوه في كتاباتهم، حتى انه

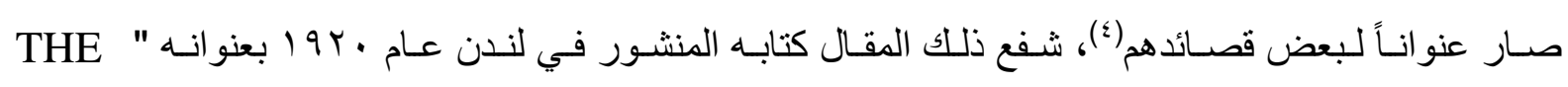
SACRED WOOD الذي تضمنَّ مقالات في الثعر و النقد، بيَّن فيه رؤيته النقدية الكاملة عن هذا المصطلح

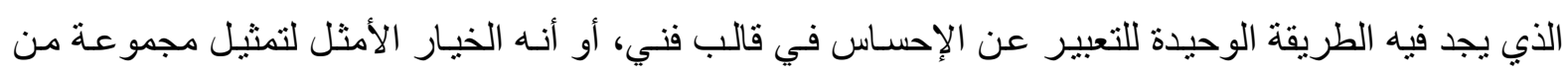

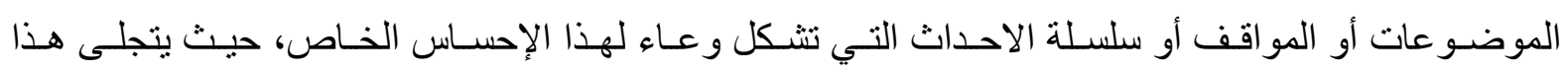

الإحساس بمجرد أن تعرض تلك الموضو عات أو المو اقف أو الأحداث مقدمة في شكل تجربة حسية(ه). 
وبذلك يمكن أن نقول ان المعادل الموضوعي هو لغـة مجازيـة تعبيريـة تخلق صور اترميزيـة قادرة على

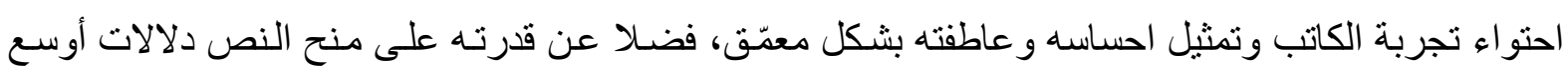

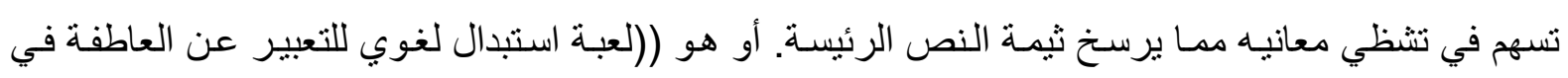

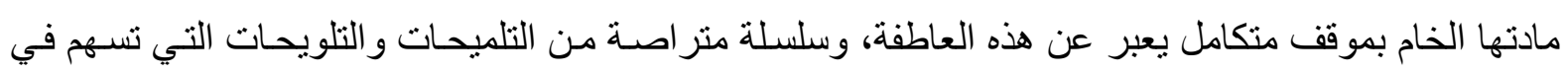
تدفق الدلالة المرجوة وتحقق الإثارة المبتغاة في المتلقي بطريقة غير مباثرة))("). وبشكل موجز، هو مصطلح

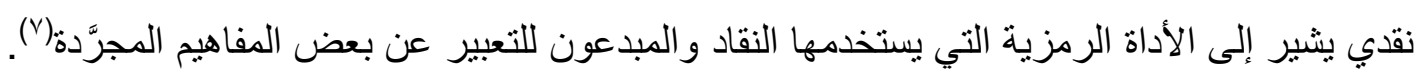
كما ان توظيفه في المنون الفنية ليس لغايات جمالية أو زخرفية فقط، بل إنه فوق ذلك يعد عاملا أساسيا

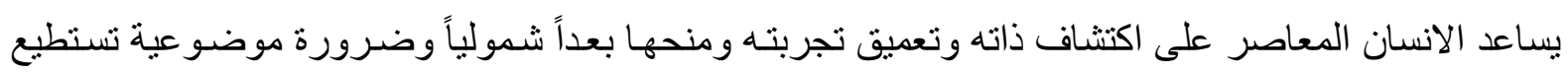
النهوض - بما تمتلكه من طاقات متجددة - بعبء الهو اجس والرؤى والأفكار المعاصـرة(^)، فالقاصـة و الروائية

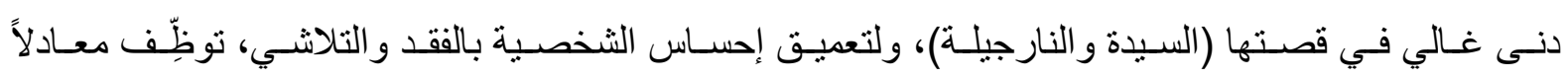
موضو عياً مكَّنها من تمثيل سأم هذه الثخصية واحساسها بالتشظي، هذا المعادل الموضو عي هو النارجيلة التي تشتريها وهي في بلاد غربتها بعيدا عن وطنها العراق.

إن الثكل الخارجي للنارجيلة ابتداءً من العنق النحيف إلى الر أس الذي تعلوه الفضة وحتى بطنها الواسعة

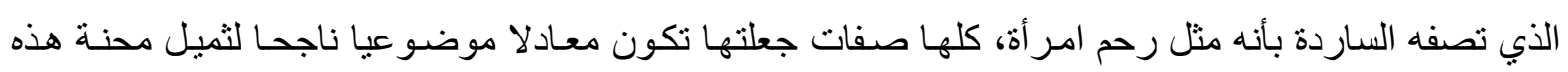
الساردة المغتربة: ((فم الزجاجة مغلق بأنبوب فضـي محزز، رشيق طويل ينهض بقامـة النارجيلة [...] هكذا

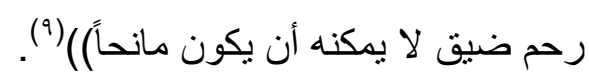
إن لتوظيف الأسماء (فم، قامـة، رحم) في الاقتباس السـابق، قد منح النارجيلـة كيانـاً موازياً لكيان السـاردة نفسها، وما ذلك إلا من أجل أن تغدق عليه القاصة ما تريد تمثيله من مشاعر، فضلاً عن أن النارجيلة قد اتسمت بسمة أخرى و هي أنها تُعَد خصيصا لاستعمال الرجل، مما بمنح هذا المعادل بعداً نرميزياً وايديولوجياً واضحاً، يتجلى في كون المر أة ربما تتشيَّأ كي تكون مجرد قطعة في البيت لبس لها فعل أو وجود في الحياة إلا من أجل استعمال الجنس الآخر، لذلك فهي عندما تتأملها من بعيد تتبدى لها وكأنها امر أة تمانلها في الحزن والضي ونيق

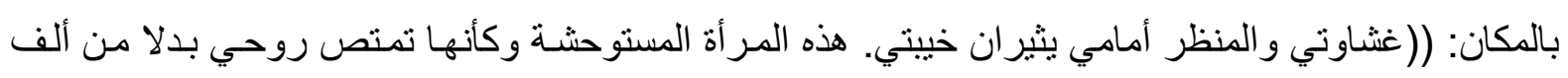

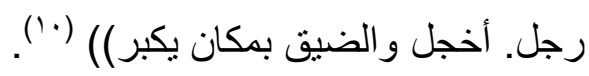

بتجلى في هذا الاقتباس البعد الترميزي الذي منحته القاصة على النارجيلة جاعلة منها امر أة لها مشـاعر الأسى و الحزن نفسها التي لدى الساردة: ((النارجيلة تلتقت إلى النافذة متحسرة. لا تحب في هذا النهار الخريفي

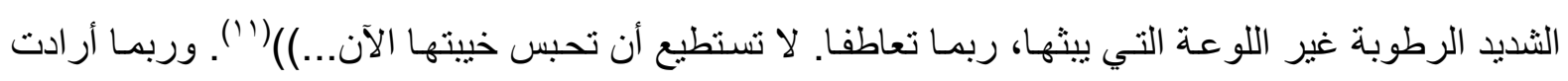

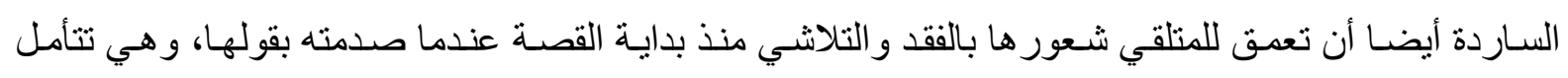

تنظيفها لجسد النارجيلة: ((حركة قطنية دائرية حثينة نزحف ببطء تلغي الوردة بعد الأخرى))(r'). إن حركة يديها هذه تشبه حركتها داخل البيت، فهي حركة دائرية حتيثة تزحف ببطء تلغي وجودهـا، وتنفي

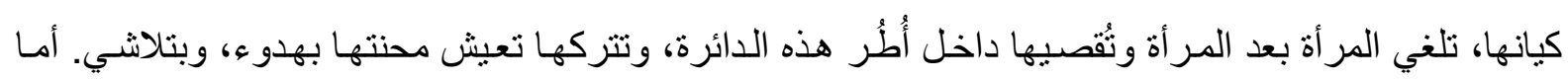


قصة (أزمنة ر اكدة) للقاصة والروائية إيناس البدران، فإن الساردة توظف سمكة الزينة معـادلاً موضو عياً لحسال

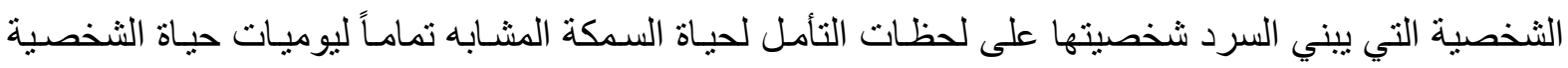
أيضاً، فينتج من ذلك كله صورة للشخصية تتحدد بالانكسار والتلاشي و عبثيـة حياتها ولا جدواها، الأمر الذي يلي يفضي بها الى الاكتئاب و الحزن: ((مسـار اتها كلها منحنيـة تتنهي حيث ابتدأت، يضمها عالمها المـائي الصغير بدعوى حمايتها من آخر كبير مخيف، هكذا لخَّصت دورة حياة سمكتها الذهبية)(ب) (َ'). المسار ات المنحنية والابتداء من جديد في كل مرة بلا تقدم وبعبثية واضحة، عالمها الصـغير والآخر المخيف، كلها ترميز ات تضخمت في هذه السمكة لتكون معادلا موضو عيا يستجلي محنة البطلة، ويسلط الضوء على احساسها بالققد و التشظي في هذا العالم المنحسر بها و عليها. كما أن هذا العالم الذي يضيق بها يناز عها فيه (آخر)، يتحكم بها، ويرسم مصير ها كما يريد، لأنها تعيش على هامش الحياة كيانـاً (آخر): ((تحدق في الوجها الصغير[...] تتأمل انسيابية جسدها]...] دور انها في قوقعتها البلورية. كانت ما أن تصل نقطة بعينها حتى تعود

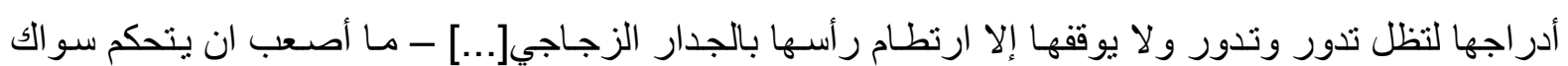

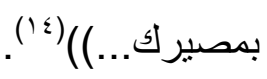

كان لتأمل الثخصية الساردة لسمكة الزينـة تداعياته على أحاسيس البطلة وشعور ها بالتشـابه الكبير بين حياة الاثنين، فالسمكة تدور وتدور داخل حوضها الزجاجي، وهي أيضاً نظل تدور لتعود لنقطة البداية، يتخلل ذلك الدوران

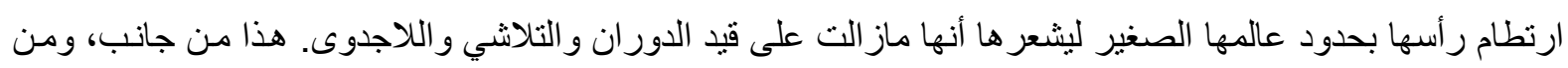

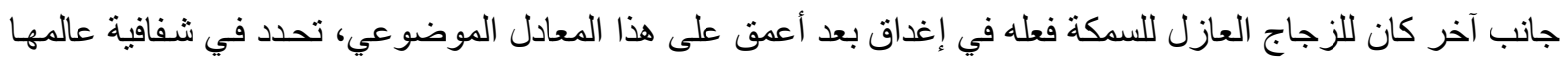

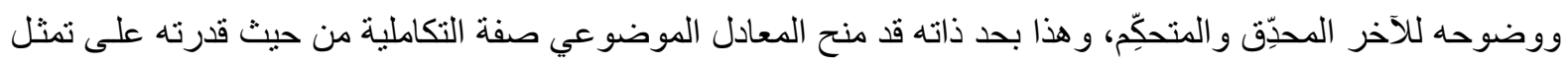

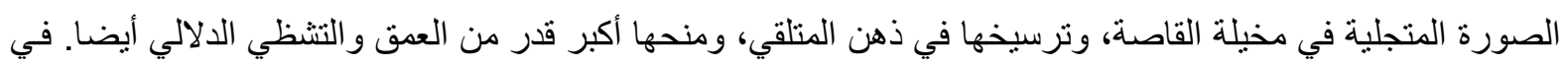

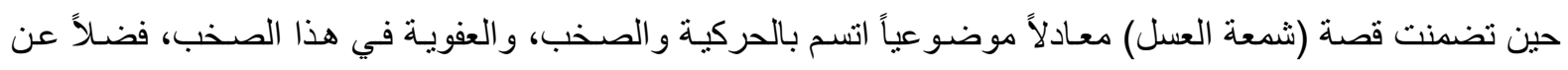

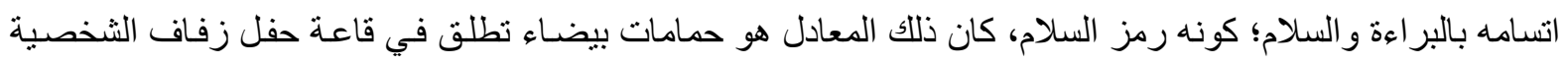

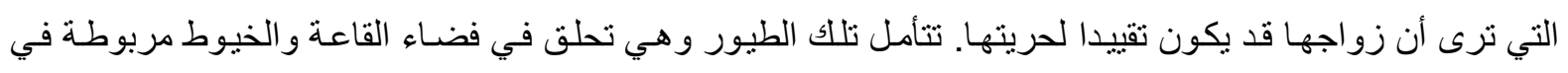

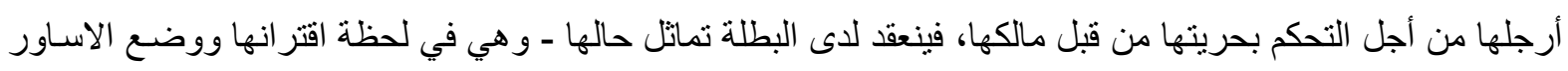

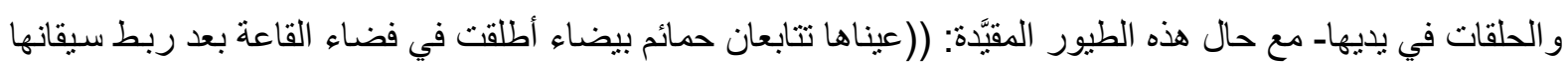

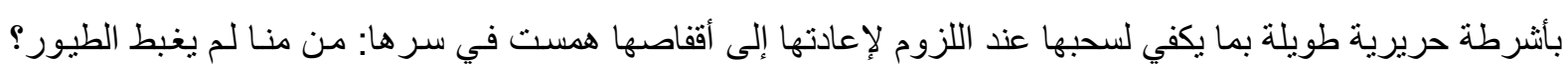

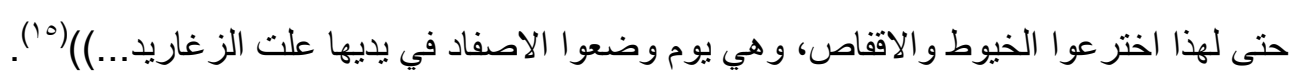
و على الرغم من أن تركيز البطلة وتأملها انصبَّ على سيقان تلك الطيور واشرطة الحرير المربوطة بها، ومقاربتها بين قيودها وقيود الزواج وقفصه الذهبي، إلّا أن هذا المعادل لم يتضمن ذللك الترميز فحسب، بـل

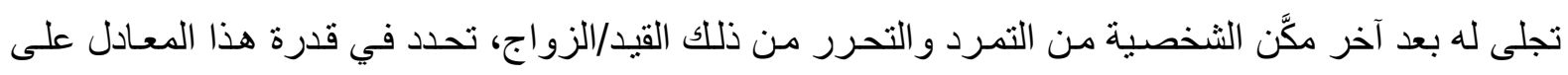

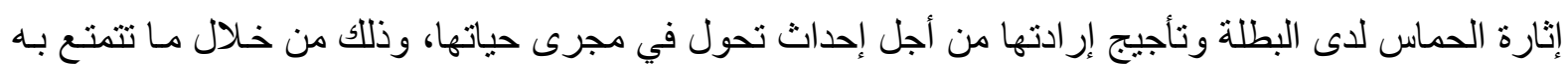
هذه الطيور من دافع للخلاص من قيودها حينما تصار ع في طير انها بعيداً في فضاءات حريتها المسلوبة، الأمر الذي شجع البطلة على محاولة التمرد من أجل الخلاص من هذا القيد الذي سيشكل بؤسها، و امتلاك حريتها التي 
على وشـك أن تُسَبَ منهـا، الأمـر الذي مـن شـأنه أن يخلق تغييراً في مجرى السـرد بشكل عـام، وفي حيـاة

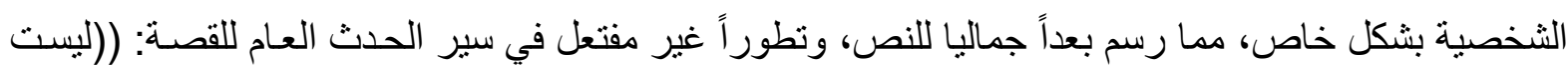
حرية من جدر ان ما انفكت تطاردها، و لا من صحبة متكلفة، و لا من مشاعر متحولة، لكنها الحريـة المنبعثة من فئن

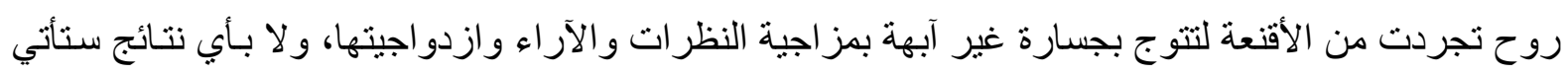

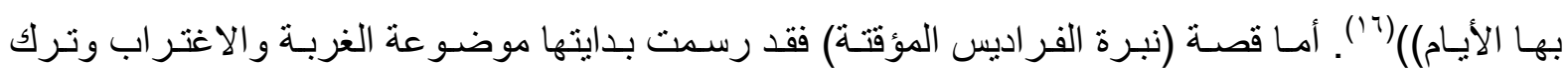

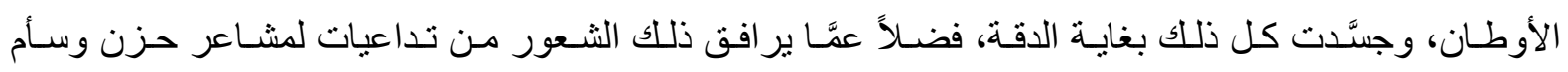
واحسـاس بالتشظي و الضياع، وهي تستعين بمعادل موضو عي مكَّن من تعميق أثر تلك الموضو عة وتكثيف معناها واستجلاء مفهومها: ((وهي تنظر إلى أسراب الطيور المهاجرة تثم "زينب البغداديـة " روائح البحار المالحة و الصحاري تنهمر من خفق الأجنحة تقول لأمها:

ـ أترين يا أمي أسراب الطيور تتجه جميعاً نحو غروب الثمس؟ إذن متى أراهاوهي تعود إلى مشرقها؟

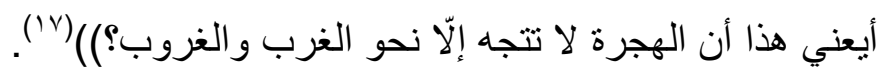

هذه التساؤلات التي تضمنها الاقتباس، وهجرة الطيور، عزز موضوعة القصـة بشكلٍ فعَالِ، وخلق للنص

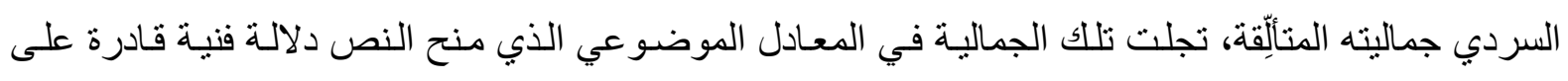
تعميق المعنى و إثـارة المتلقي بشكل يحفز لايسه التأمل حينمـا يجد نفسـه أمسام بنيتين فنيتين (بنية النص، وبنية معادله الموضوعي) تكمل كل منها الأخرى، ممـا سـاعد كثير اً على التفسير و التأويل للنص السردي، لاسيما عندما كانت النهاية قد اختزلت هذه الأفكار بإعادة التلميح للموضوع الرئيس مرة أخرى: ((انتهى الربيع..ها هي

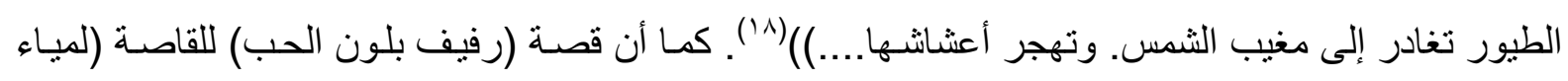
الالوسي) قد استعانت بمعادل موضوعي استجلى محنة الثخصية في النص السردي للقصـة، المتحددة بالتلاشي والضجر من لا جدوى حياتها، بعد أن فارقها أكثر أفراد اسرتها، ممـا استدعى لديها احساسـاً بغربـة روحيـة،

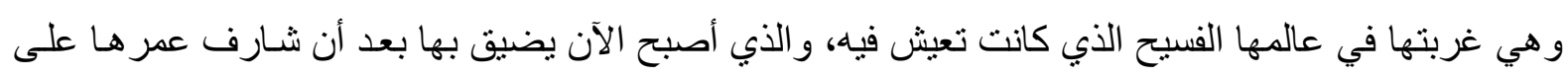
الانتهاء، تجلى هذا المعادل الموضوعي بـ "شجرة سدر" توسطت منزل هذه العجوز وهي مـا تز ال مخضرَّة

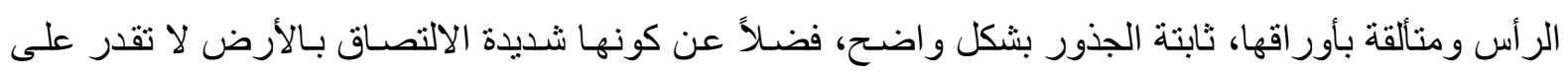

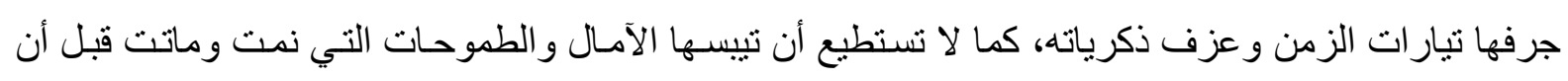

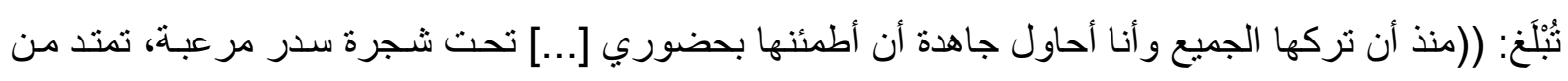

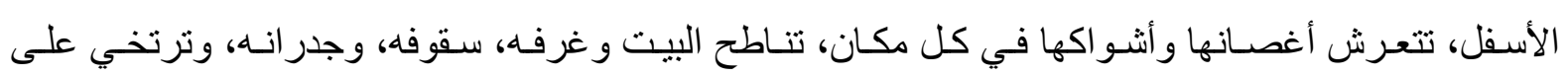

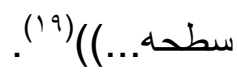

ارتسم في هذا الاقتباس معادلا موضو عيا عمدت الثخصية السـاردة على رسم ملامحهه بكل تفاصيلها

القادرة على تعميق محنة المر أة المُسنِّة، فضلاً عمَّا لثجرة السدر من قدسية واضحة، كل ذلك قد منح المعادل الموضو عي أهمية فنية للنص؛ كونه الأقدر على استيعاب كل احاسيس الساردة تجاه هذه المر أة المُسنِّة، وتمثنبلها تمثيلاً فنياً ألقى بالضوء الهيه على محنتها واحساسها بالحزن و السأم والتلاشي، بعد أن أرهقتها ذكريات هجر الأحباب 
و الأصحاب ورحيل الأهل، إذ بقيت لتلك الذكريات تصدعاتها المتجذرة في أعماق روحها: ((أعشـاش العصـافير

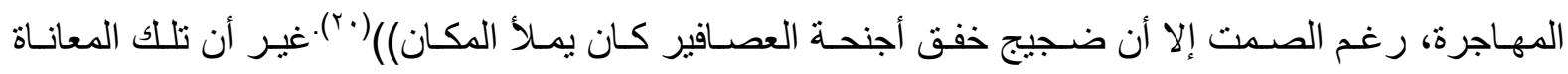

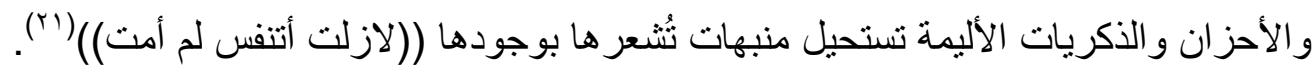

أما قصنة (جدائل الثمس) فقد وظفت معادلاً موضدوعياً صوَّر تصويراً دقيقاً مـا تُعانيه بـلاد الثخصية الساردة من حروب مستمرة وقتل وإر هاب، عندما جعلت هذه الساردة من نوازع المر أة للموت في أثناء الو لادة وشدَّة الطلق مُعادلاً موضو عياً، ففي شدَّة الطلق للو لادة كانت تقترب من الموت شيئًاً فنشيئاً، غير أنها في كل طلقة كانت تهب الحياة لأبنائها، و هذه الرؤيـة تتجلى فيها الإنسـانية بأسمى صور ها، عندما تصور المر أة بأنها

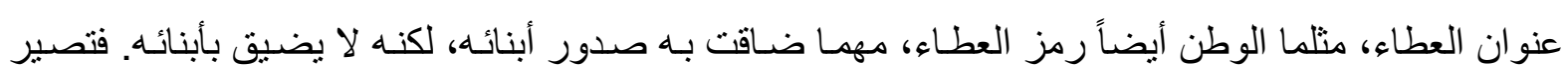

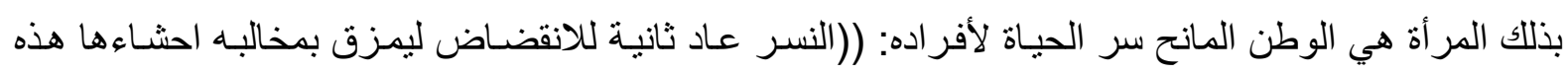

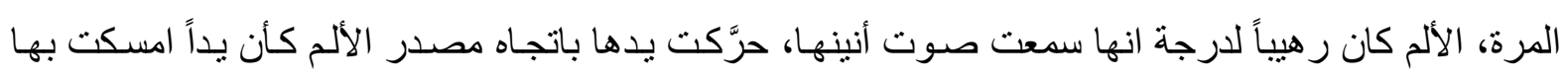

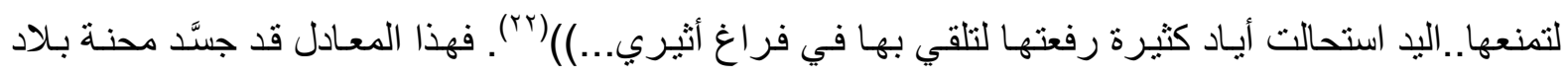
الثخصية وهي تصار ع الحياة مع توالي الفتن والأزمات، ونسور الموت والخراب منتظرة، وهي تتضور جو عاً تريد الانقضاض على بلادها، فتحاول-عند اشتداد الطلق- وضع بدها على موضع الألم، لكن الكثير من الأيادي تمنعها حتى تجد نفسـها تتلمس قضباناً بـاردة، ونسر الموت برمقها بعيون قاسية مرتقبة في انتظـار أن تسقط

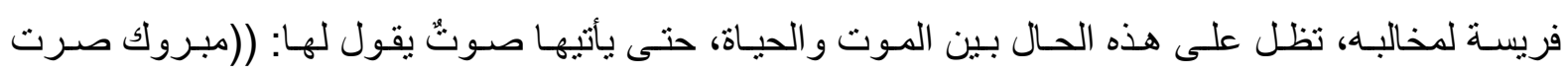

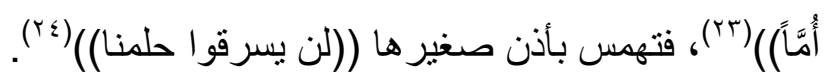
إن مساحة النص السردي للقصة القصيرة مقارنة بغير ها من الفنون السردية كالرواية مثنا أو المسرحية،

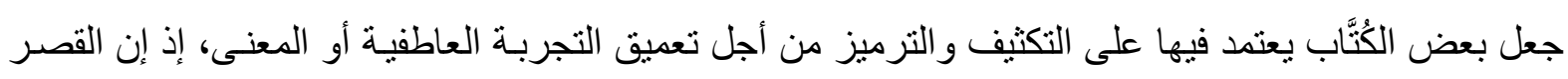
المحدود لهذا الفن قد يجعل اغر اقها بـالعو اطف والاحاسيس أمراً ليس لله مبرر على الإطلاق، هذا إذا مـاتم المقارنة بين تلك المشاعر مع حجم النص وحدثـه الذي يجري في دورة شمس واحدة، وهنـا يأتي فعل المعادل

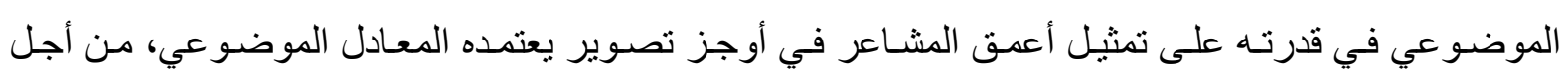
إحداث ردة فعل إيجابية عند المتلقي، تستحثه على التأمل والتأويل، كما ان ردة الفعل هذه قد لا تتأتى من البنية المُحددة للمعادل الموضـوعي في النص فحسب، بـل بتوقيت مجيئه بعد جملـة من الاحداث الصـغيرة والصـور

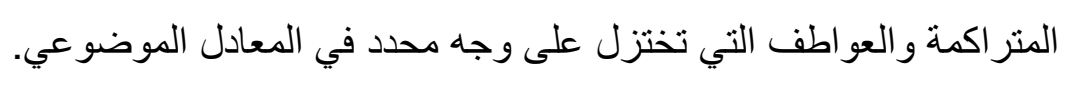

\section{المبحسث الثاني- الحهوار}

يعد الحـوار عنصـر اً مهمـاً مـن عناصـر البنـاء الفني للنصـوص السردية بوجـه عـام، ووسيلة فاعلـة مـن

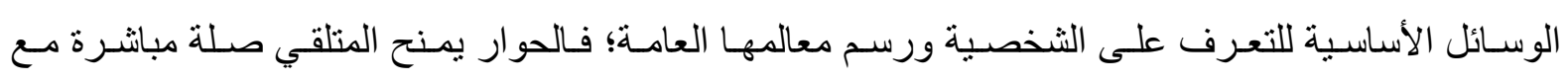
الثخصيات، ويمكنه من معرفة نوازعها الداخلية وعو المها النفسية بثكل مباثنر من غير واسطة بينه وبين الثخصيات ثُرشح كلماتها أو حتى احاسيسها التي قد تتقل للمتلقي من خلال المونولوج مثنلاً أو الأنو اع الأخرى للحوار ـ و هو أيضـاً ((عرض در امـاتيكي في طبيعته لتبادل شفاهي بين شخصيتين أو أكثر))(ro)، وهو وسيلة 
مهمهة جداً في عرض الثخصيات وتقديمها من خـلال مـا يعرضـه من صـر اع بينها يؤدي إلى إنجاز هـا على

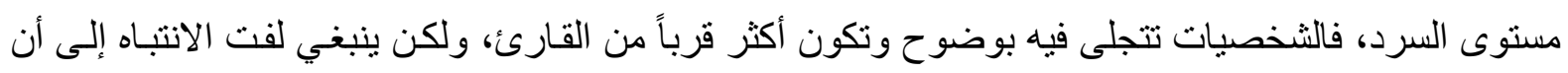

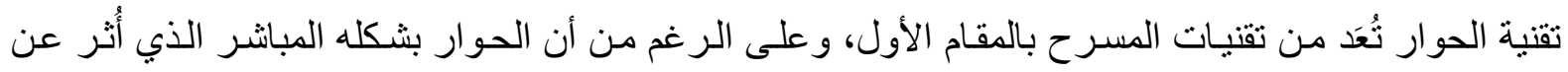

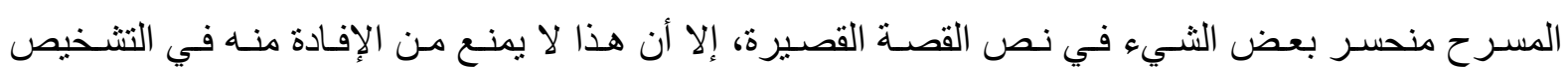

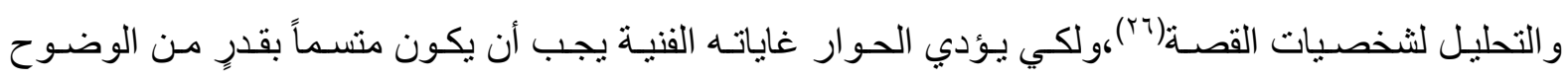

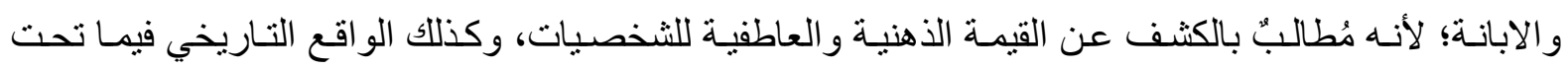

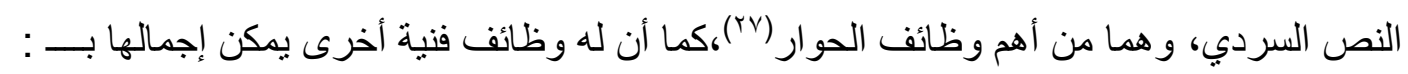
تمكنه من رفد القصة بالمعلومات الكافية لافعها إلى الأمام، لاسيما إذا تضمن صر اعاً بين الثخصيات مع شيء من المفاجأة، فالصر اع بين الثخصيات المتحاورة التي ترغب كل منها بتحقيق التفوق على الأخرى، يؤدي خدمة كبيرة للنص المسرود في إيضاح معالم الثخصيات و انجاز ها على المستوى العام للسرد، فضلاً عن تمكنه

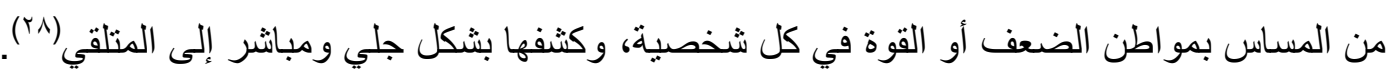
تتجلى له وظيفة أساسية أيضاً تتحدد في قدرته على أن يرينـا الثخصيات(r9)؛ لأنها يمتلك القدرة على ربط تلك الثخصيات وحصر ها في مجالٍ واحدٍ، وفي موقف واحد أمام عيني القارئ. تحقيقه المصداقية في نقل العبـار ات ومـا تنطوي عليه من مشـاعر وأحاسيس؛ ذلك أن الكلام العُقََّّم بالثََّّرطَة يتضمن إيحاءً بالحرفية الحقيقية للكلمات المنقولة من الثخصية بشكلها المباثر (·r). من ذلك كله يتضح أن الحوار يكتسب أهميـة كبيرة في دراسـة الفنون السردية، وقد أُعطي حيزاً خاصـاً لدى بعض النقاد، أهمها ما توصل إليه "جيرار جينيت" في در اسـاته التي أثمرت عن تمييزه لثناثِ حسالاتٍ من

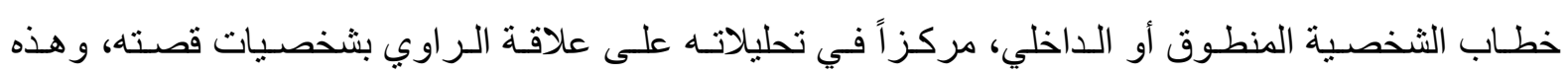

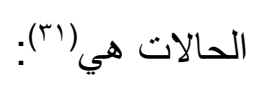

ا. الخطاب المسرود أو المروي: ـ الذي يُكتَفى فيه بتسجيل مضمون الكلام فقط. r. الخطاب المحوّل بالأسلوب غير المباشـر: - الذي يبرز فيه حضور الراوي بشكلٍ فاعلٍٍ حينمـا لا يكتفي بنقل الأقو ال حرفياً، بل يُكثفها ويذوبها في خطابه الخاص معبراً عنها بأسلوبه. r. الأسلوب المباشر أو المنقول: -الذي يتم فيه نقل الكلام حرفياً من غير تعديل أو تغيير. ولكن، بعد أن ظهر الاتجاه النفسي وكَثُرَت الدراسات و الأبحاث الحديثة في علم النفس التحليلي، لاسيما أبحاث (فرويد) في العقل البشري، تأثر الحوار بتلك الدراسات بشكل كبير إلى درجـة أن تنَّ تقسيمه-بحسب تلكانك

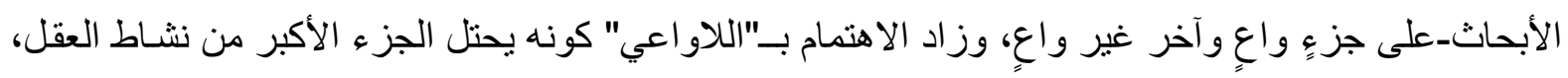
لذا ظهر أسلوب جديدٌ في الحوار يختلف عن سـابقه في تقديمه المحتوى النفسي للثخصيات عن طريق الكلام غير المسموع و غير الملفوظ، أو ما يسمى الحوار الداخلي أو (المونولوج)، أو (تيار الوعي)(rr). 
وبنـاء على مـا تقدم سيقف هذا المبحث على بعضٍ من نمـاذج الحـوار بنو عيـه الصـامت (المونولوج)

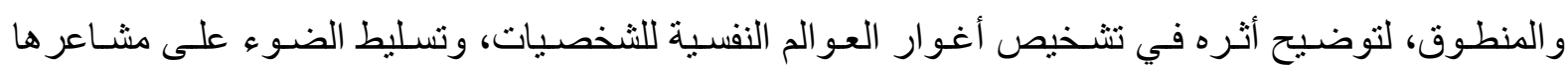
واحاسيسها، والكثف عن معاناتها وعلاقتها بذاتها والآخرين ممن حولها، مما بيساعد على فهم أكثر للشخصية. كان الحوار في قصة (قضبان من ذهب) للقاصـة "كليزار انور" قد ألقى الضوء على الدواخل النفسية

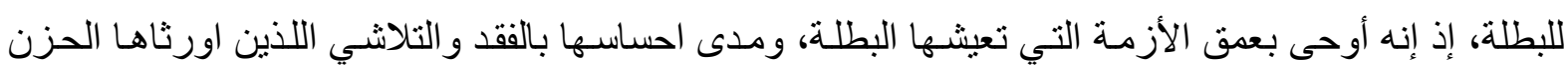

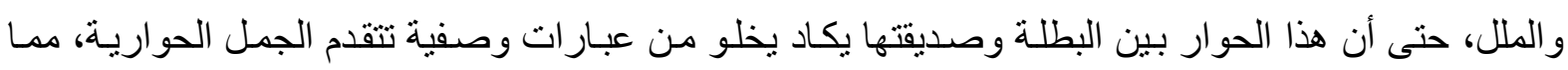

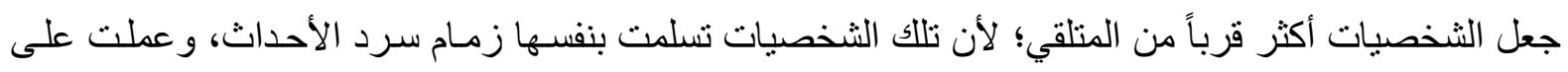
تصوير نوازعها والإفصاح عن مشاعر الكبت التي تعتمل في دواخلها بكل حريـة، وبشكل مباشر عن طريق

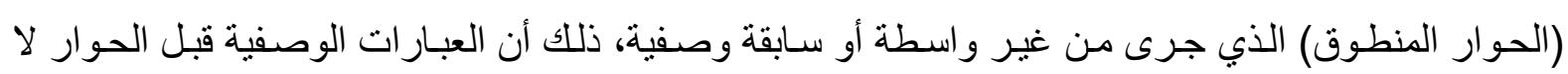

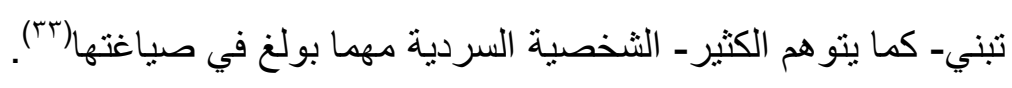
((- في قصري كل شيء.. لكن، ليس فيه ما يملا القلب! رَدَّت و الدهشة تملأ أسوار وجهها: ـ أيُعقل! الكل يحسدك.. تسكنين قصر اً رائعاً على أعلى رابية في البلد.. تنتزينين بأغلى المجوهرات .. ترتدين أحدث الموديلات. ـ لكنها تبقى مظاهر فقط.. وكل هذه المظاهر لم تستطع أن تمحو نظرة الحزن في عيني ودمعة الألم في قلبي... استأثرت الثخصيات، في هذا الحوار الذي بستمر طويلاً، بـالكلام من غير راوٍ يروي عنها أو يكون وسيطاً بين الثخصيتين، لذلك حاولت البطلة أن تفصح بنفسها عن عمق أزمنها، لعدم تقتها براوي يروي عنها فئريا

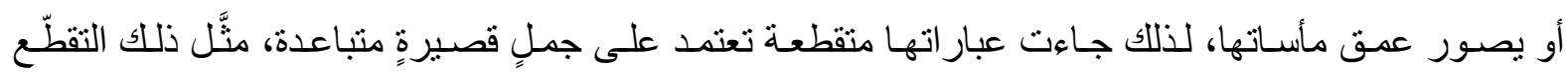
و التباعد النقاط الفاصلة بين الجمل، والتي توحي بمر ارة الأزمة النفسية التي تعيشها الثخصية، مما جعل كلامها غير منساب بشكل عفوي أو مسترسل، فضلاً عن تكرارها للكلمات (كل، ولكن) فكلمة "كل" تدل على الثمول، أي أن كل ما يحيط بها يعمق احساسها بـالحزن و اللاجدوى، أمـا كلمـة "لكن" التي تفيد الاستدر اك، فقد وظفتها بعد كل عبارة تحاول الاستدر اك فيها بـأن مـا تعيثـه ليس بذي جدوى، وهو أيضـا سـر تعاستها. كل ذلك عزز لديها حالة الانكسـار، وشخَّص بوضوح شعور ها بـالحزن المكبوت في قاع روحها مثل مر برار ينخر الأحشّاء ويصهر القلب في بوتقة الإحساس باللاجدوى.

يطبق ذلك الإحسـاس على البطلة إلى درجـة أنها تشـعر بعقم هذا الواقع من أن يلبي إسـعادها، لذلك تحاول التنفيس عن تلك الآلام، من خلال تدوينها على الورق كمذكرات لها تفرغ فيها ماتعانيه من كبت؛ لغياب من يملك حس المو اساة ((عندما لا يحقق لنا الواقع ما نريد فإننا نلجأ إلى الحلم الذي نراه في الورقة. غمدت القلم 
بقلبي المتألم وكتبتُ لأنفّس عن بعض المشاعر الحبيسـة في داخلي.. لكن، كل مـا كتبته وجدته ممزقا في درج مكتبي...(ro)

ويـاتتي الحسوار في قصـة (انعكاسـات امـرأة) بين الأم وابنهـا الأكبر ليكثَف عن شـعور المـر أة الواعي بإقصائها وتهميشها، أو على الأقل بتثبيئها، حينما حمَّلت هذه المر أة سؤال ابنها أكبر قدر من الدلالات لمدلو لات تؤكد هامشيتها في الحياة: ((- أمي لماذا تهتم المر أة بجمال مظهر ها؟ لسؤ اله طعم الصدأ، وكأنه ودَّ لو فال "أمي لماذا لا تبحثنين لك عن تربة لتتدسي فيها متلفِّعة بالسواد حتى

$$
\text { يو افيك الأجل؟" قالت: - حتى أنت يا... ثم أكملت محاولة ترويض صبر ها. }
$$

كان سؤال الابن، وطريقة استقبالها له، قد صوّر بشكل مموه عدم رضـاها بحالها وأثر هـا المحجَّم داخل

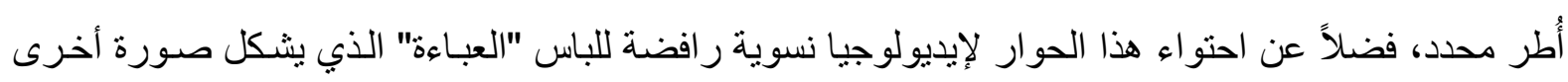
من صور الاحتو اء والتنميط و الإقصاء الأبدي ،بدلالتة عبارتها الأخيرة ( لمـاذا لا تبحثين للك عن تربـة لتندسي فيها متلفعة بالسو اد حتى يو افيك الأجل) وقد عمل السؤال أيضـاً كمؤكدٍ قُصد منـه تقديم معلومـات، إذ إن الأسئلة نفسها هي نوع خاص من الطلب؛ أي تطلب معلومـات، لكن السـائل في هذا الحوار لا بطلب المعلومـات، بـل يقدمها، عندما يقصد من المتلقي أن يعي بأنه يريد جواباً عن سؤاله، فيصير الجواب في حدّ ذاته توكيداً لمـا يريد

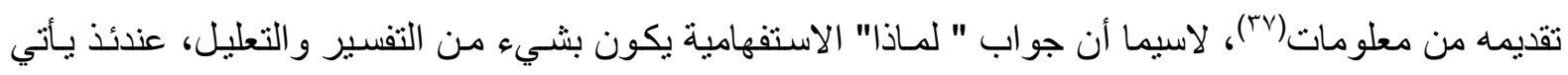

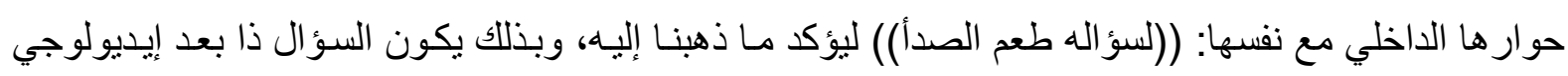

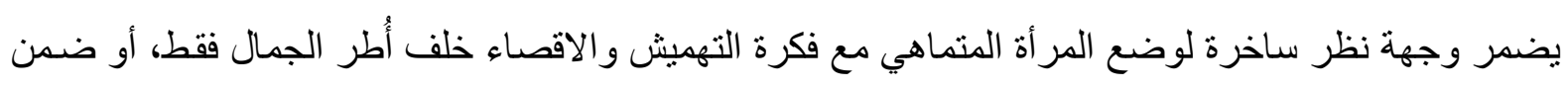
حدود التلفع بالسو اد، تلك الأطر والحدود التي رسمها لها المجتمع الأبوي وفرضتها عليها سلطته القامعة منذ فئ الأزمان.

وفي قصة (الثمس السوداء) يأتي الحوار المنطوق على شكل سؤال وجواب بين رائد فضـاء بهبط إلى "الثمس السوداء" التي ترمز إلى بلد الثخصية/العراق، بعد أن أعجبه سحر هذا البلد وجماله. يتكفل الحوار الذي كاد أن بطغى على النص بأكمله بإلقاء الضوء على معالم البيئة المحيطة بالثخصيات ورسم معالم هذا البلد

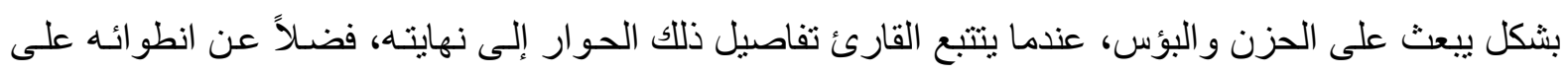
بعد تأريخي تجلى في اختز اله للأحداث التي مرّت بهذا الكوكب/العراق، وكيف كانت الناس تعيش فيهـ أيسام حكم صدام حسين، وتغير الحال بعد دخول السلاحف الرماديـة التي ترمز لدبابات الاحتلال الأمريكي: ((آنستي من فئسئ فضلك ..في أي كوكب نحن؟....

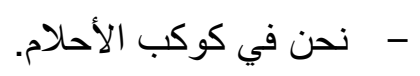
قلتُ مستغرباً الاسم: - الأحلام! سألت: 
قالته [كذا] كأنها تنفي تهمة:

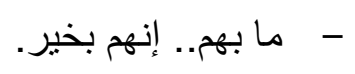

قلت مستدركاً: - أعني إنهم بتحركون كالآلات..لا أدري هنالك شيء ما غير طبيعي .

$$
\text { قالت: - لو إنك رأيتهم فيما مضى. }
$$

- وكيف كانو ا؟ سألتها بفضولي المعهود. قالت متلعثمة:

ـ كانوا يساقون في أعمال السخرية كالعبيد وير غمون على السجود للإمبر اطور.

أكملت وكانها تحدث صديقا.. وكما تعلم فقد حكمت السلاحف الرمادية مكانه.. سأل:

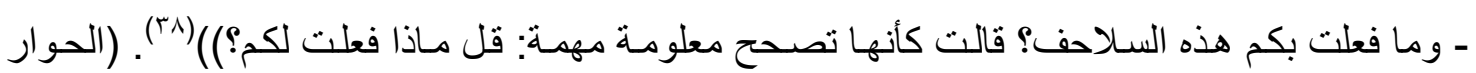

المنطوق) "يستمر على هذه الثـاكلة حتى نهايـة القصـة، وبرمزيـة مفضوحة ترمز للعر اق "أرض السو اد" إبـان

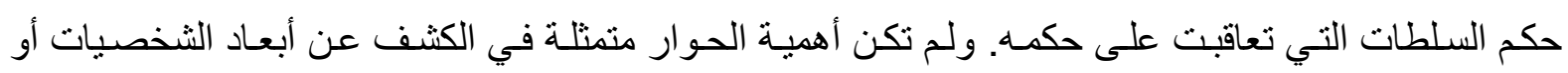
جو هر ها بالمرتبة الأولى، كما في أغلب الحوارات القصصية، بقدر ما حاولت الإفصاح عن الفكرة المتجلية في

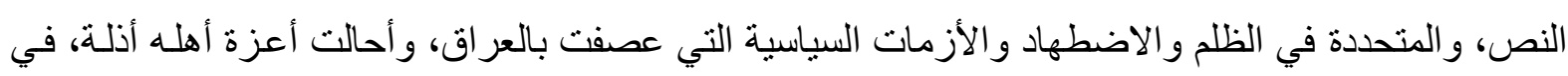

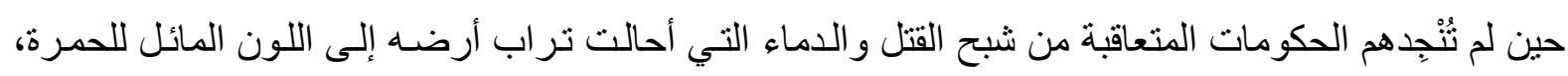
و هو ما لفت اهتمام هذا الرائد الفضائي كي يستعلم ما حل به.

إن حالة الحزن و البؤس لم تلحق بشخصية واحدة في القصة، كما في الأمثلة التي سبق التطرق إلبها، بل

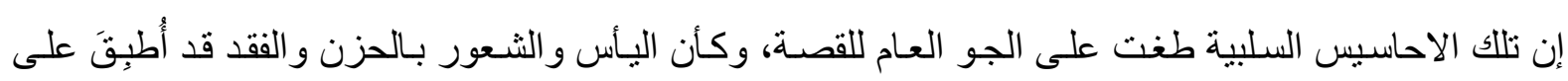

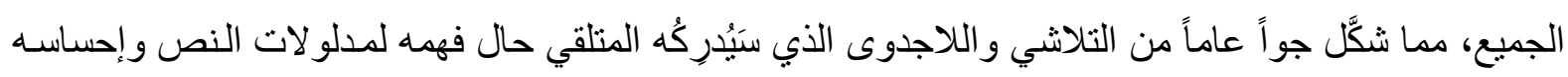
بها، و اكتشافه لترميز اته المبثوثنة في مبناه الحكائي.

أمـا في قصـة (الرصيف الآخر) فـإن السـرد يسبر على وفق أسلوب المونولوج الداخلي، إذ ألقَى هذا

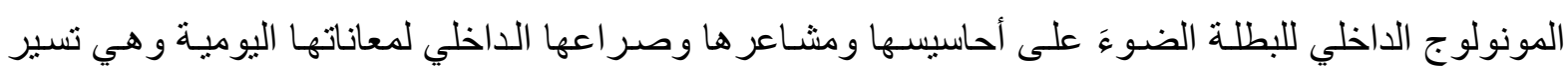

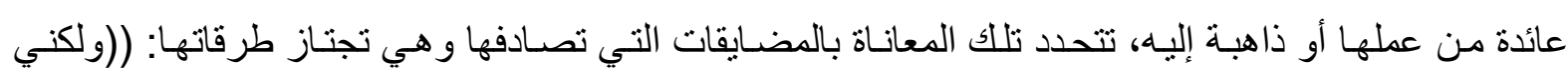

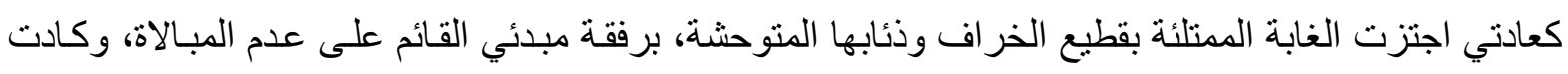
عيون الو اقفين تلتهمني وتسحقني تحت وطأة التمادي الو اقع علي والجر أة المشحونة بالخبث و الإصر ار العنيد.. كلا، لن أبـالي... إنني لم أقترف ذنبـاً كي أعامل بهذه الطريقة الجارحـة... لا شيء بـي يغري ذلك المعتوه،

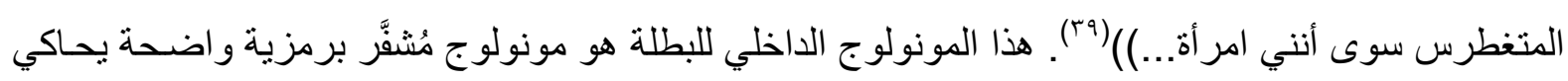
النظرة الدونيـة للمر أة، ومـا تقاسيه من ألم أو مـا تعيشـهـ من إحسـاس بالسلبية جرَّاء تلك النظرة التي تو ارثتهـا المجتمعات عن المر أة. 
تدحض هذه القصة أيضاً الفكرة القائلة إن الأمكنة المأهولة بالناس تتسم بالألفة، فعندما تنادي "مارسلين

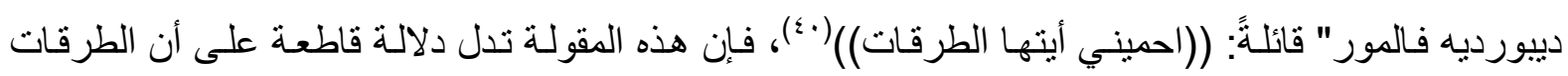
جديرة بتوفير الحماية للآخرين الذين يطرقون خطو هم فيها؛ كونها مأهولة بالناس مما توفر لهم الأنس نوعا مـا، وكونهـا أيضـاً قـادرة على تبديد الوحشـة التي تضفيها الأمكنة الخاليـة، فضـلاً عن اتسـامها بالسـعة اللامتتاهيـة و الانفتاح، غير أن البطلة في هذا النص السردي، ومبناه الحكائي المنسوج بدقة، أثنتت الضد من ذلك، فقد برهن

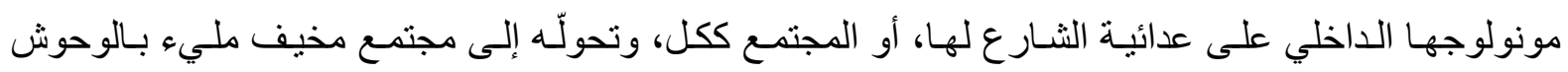

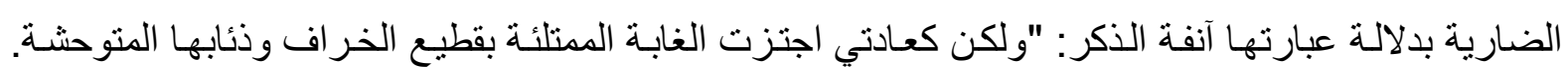
برفقة مبدئي القائم على عدم المبالاة".

لقد حمَّلت القاصـة (الثـارع) الذي ارتسمت صـورته بوضوح في مونولوجها، أكبر قدر من الدلالات لمدلو لات متنو عـة شديدة الحساسية بقضية المر أة ورؤيتها لذاتها وللعام من حولها، بل ورؤيسة ذلك العالم لها أيضاً، فقد تمكَّن هذا المونولوج من إلقاء الضوء على على أبعاد الثخصية النفسية والجسدية أيضـاً، وصور تصويراً

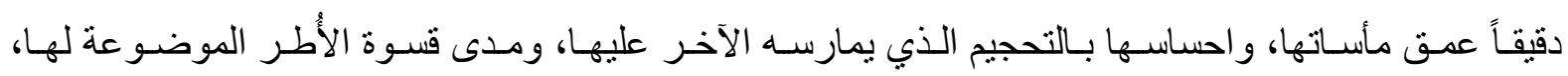
و القو الب المُعَّدة لهـا سلفاً، فضـلاً عن قدرة ذلك المونولوج على الإفصساح عن صـلابة هذه الثخصية وقوتها

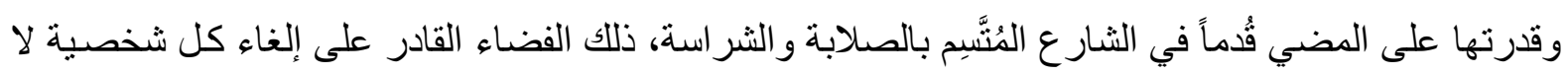
تحسن وضع أقدامها عليه، كما أنه يلغي أيضاً كل فكر لم يحسن الدخول إلى زوايـاه المظلمـة أو المعتمـة أحيانـاً،

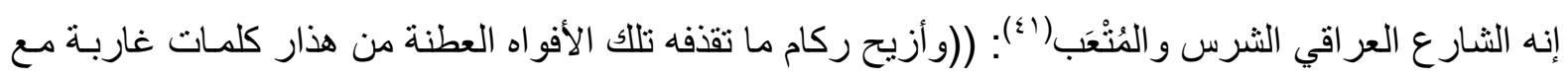

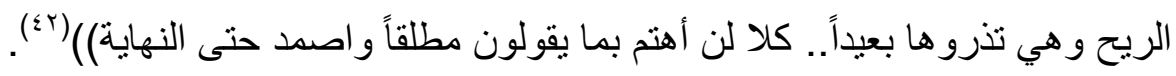
نجح هذا المونولوج في الكثف عن الأفكار الباطنية للشخصية بكل وضوح وفنية، فضـلاً عن أنه شكَّل عدائية ذلك المكان لها والذي لا يفتر يذكر ها بتحديق الآخرين لها وتحجيمهم إياهـا، وبذللك يكون للمكان بعد إيديولوجي تجلى في قدرته على استيعاب قضية الثخصية، وتمثيلها بمسحة من الواقعيـة الترميزيـة، في تأكيد لا إنسانية النظرة الدونية للمجتمع إلى المرأة: ((أعصابي ما زالت متماسكة ولم تخر قواي، ولم تعجز عن اتخاذ

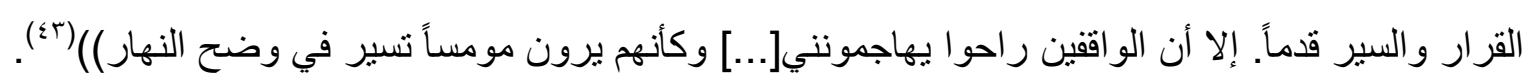
المتلقي الكفه الذي يتأمل هذه الصورة المتحركة للثخصية المأزومة، سوف يُدرِك أن كل مـا يجري في

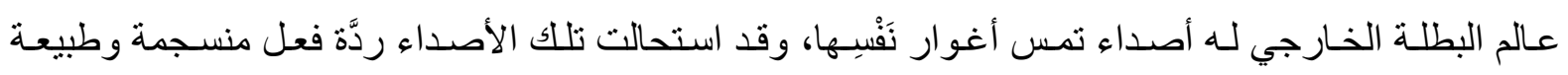
الثخصية الصامتة، ففي حركتها وهي تسير في الثار ع ترفع قدم وتسحق بالأخرى أرضية الرصيف ومعها كل

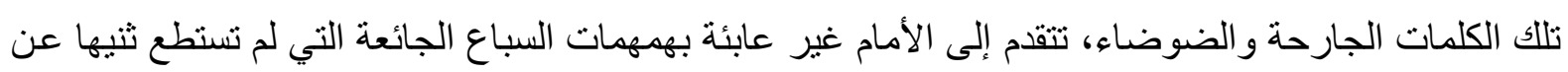
تقدمها أو تقدميتها. ومن الملاحظ أن هذا النص جعل من المكان "معـادلاً ترميزيـاً " اسقطت عليه الأنـا السـاردة إحاسيسها السـابقة، برفضها أن تكون مركزاً للتحديق الحيواني، فقد كان للعلاقة المتبادلة بين البطلة و المكان

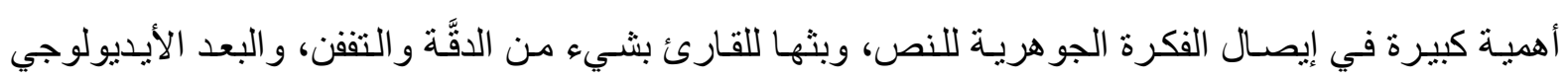
الترميزي أيضاً. 
في قصة (لحظة اكتشاف القمر ) يستجلي مونولوج الثخصية احساسـها الواضـح بالفقد و التلاشي، ممـا

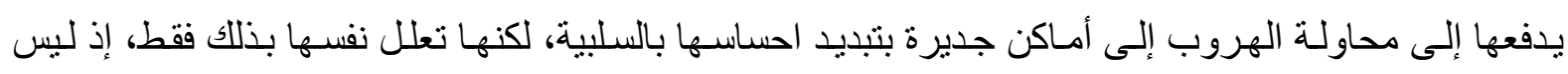
هنالك فضاء كفيل باحتو اء محنتها وتفتيت احساسـها بالتشظي و الفقد: ((أهرب منهم معهم ليقودوني إلى أمسكن احبها، تشـرني بالأمسان، تقتل اغتر ابي أو تشـله، لا فرق فأنـا ممتلئة بالأسى الذي يقترب مني ومنهم، درت

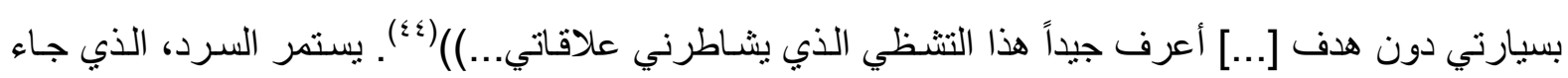

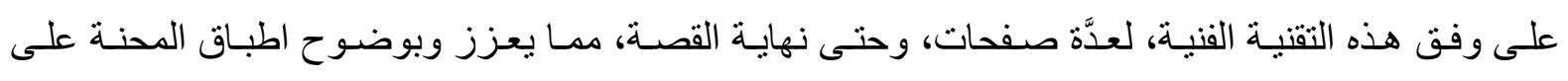

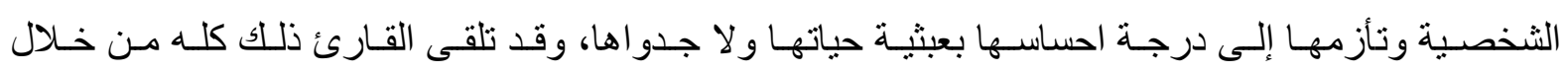
مونولوجها وصر اعها الداخلي الذي رسم بدقة الاغو ار النفسية للشخصية، وشكَّل أبضا أبعاد و اقعها المرير الذي وني

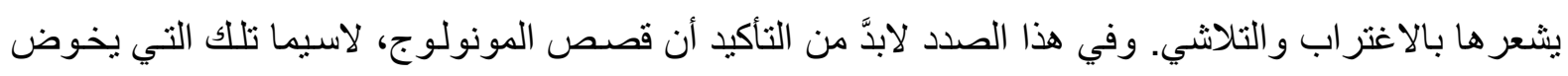
فيها البطل صِر اعاً داخلياً مع ذاته، فإنَّه يصعب أن ينتهي ذلك الصـر اع أو حتى القصـة ككل نهايـة حاسمة؛ لأن

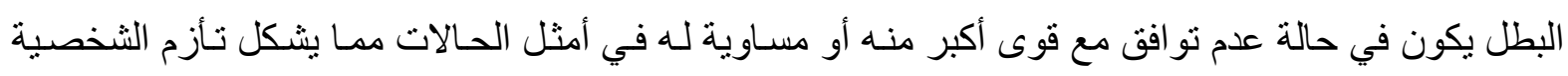

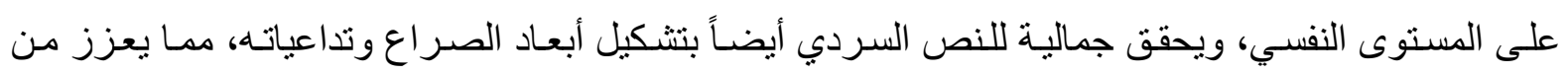
انجاز الثخصية وتكاملها على مستوى السرد.

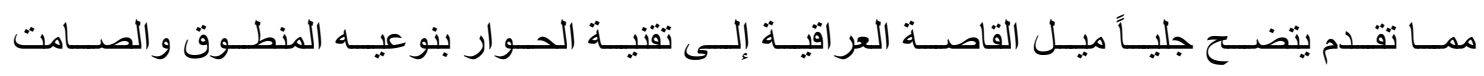
(المونولوج)(0) في تقديم الثخصيات، وتشخيص أبعادها النفسية والجسمية، وتصـوير محنتها وتأزمها، فضـلاً عن سرد الأحداث وتثكيل المتن الحكائي للنص ومبناه بدقة فنية واضحة، وقد وجد الباحث ـ ممـا يتعذر إثباته

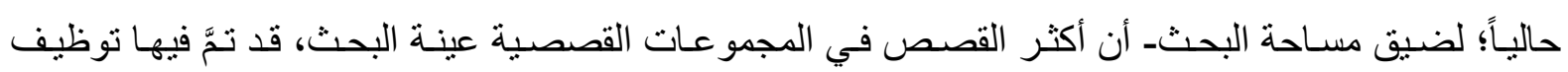
الحوار المنطوق مع الاستعانة كثيراً بـالحوار الداخلي لمؤازرتـه في دفع الصـر اع إلى الأمـام، ممـا يؤكد وضـع

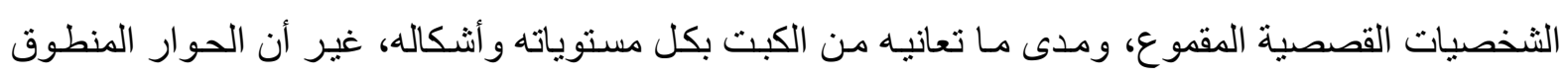
جاء ليعزز خروجها من دائرة القهع ويضفي عليها شيئًاً من التمـرد و الرفض، و التحليق في فضـاءات الحريـة

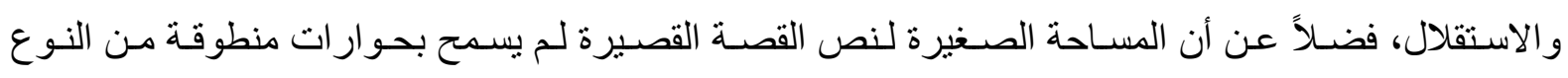
المطوَّل في تقديم الثخصيات السردية ورسم ملامحها الداخلية واحاسيسها، لذلك يتم توظيف تقنيات أخرى لمساندة الحوار، و أقصد به مثنا تقنية الزمان باسترجاعاته واستباقاته، وهو ما سيتم عرضه في المبحث الآتي.

\section{المبسحث الثنالث- الزمن السـردي}

يعرَّف الزمن السردي بأنه مجموعة العلاقات الزمنية كالسرعة أو التتابع أو البعد ...الخ، بين المواقف والمواقع

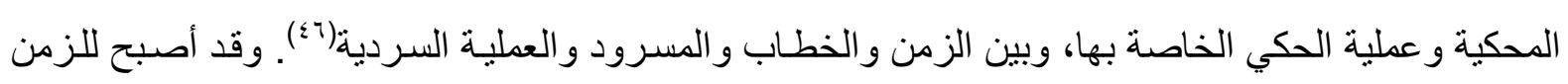
في السرديات الحديثة أهيـة واضحة؛ لما يترتب عليه من نشويق للقارئ، وقدرة كبيرة على إحداث الإيقاع و التتـاغم في النص المسرود و ابعـاده عن الرنابـة والسكونية، فضـلاً عن كونـه محدداً لدو افع محركة أخرى، كالسبيية والتتابع واختيار الأحداث وتسلسلها في النصوص السردية، كما أن لله قدرة فائقة على التأثنير في كلِ 
أجز اءِ النص السردي و عناصره ومكوناته؛ وذلك لتمكنه من التغلغلِ داخل نصّـه بشكلٍ لا يمكن استئصساله منـه

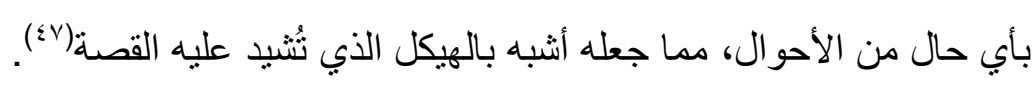
من ذلك تتضح أهميته لفن القصة الحديثة بِعدِّه عنصر اً رئيساً فيها لا يمكن الاستغناء عنه من غير أن تفقد

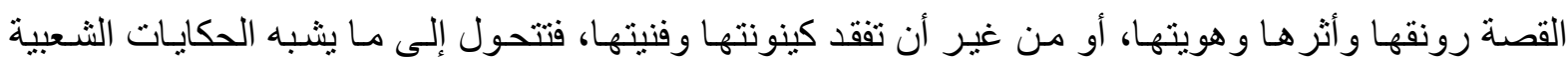
القديمة التي تتصدر ها عبارة "كان با ما مكان في قديم الزمان". و استناداً إلى ذلك تكون القصة الحديثة هي أكثر الأنواع الأدبية تمسكاً بالزمن و التصاقاً به(^§)، و وان القاص أو الروائي لا يتوقف أطلاقاً عن كثرة التفكير بـه بعدِّه مسألة صعبة المُرتقى، وكثيرة الإلحاح على التقادم ومضي الزمن سواء على سير الاحداث في المتن الحكائي

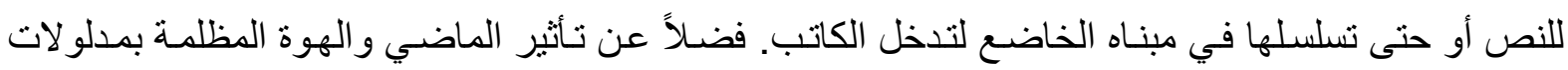

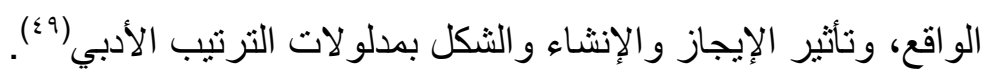
و لابد، قبل الشروع بعرض التطبيقات للنصوص القصصية، من تأكيد ملاحظتين مهمَّتنين، أولى هـاتين الملاحظتين تتمثل بندرة التطابق بين تسلسل الأحداث وترتيبها في المتن الحكائي من جهة وتسلسلها في المبنى الحكائي للنص المسرود من جهةٍ أخرى(•)، فتسلسل الأحداث وسير ها في المنن الحكائي يمكن أن يكون:

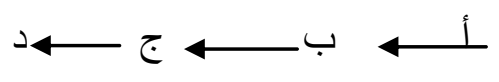

أما في المبنى الحكائي الخاضع لتدخل الكاتب وتلاعبه به فقد لا يكون بالتسلسل السـابق نفسه، بـل يكون

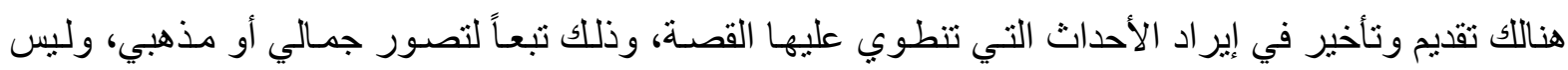
حسب تسلسل الأحداث في الحكاية. الملاحظة الثانية تتمثل في وجوب القناعة والتأكيد أنه ليس من المعقول أن يكون- مثلاًَ- ثناث سنوات من حياة البطل ملخَّصة في جملتين أو أكثر من قصة معينة، ما لم يكن هنالك تلاعب في زمن النص المروي وزمن

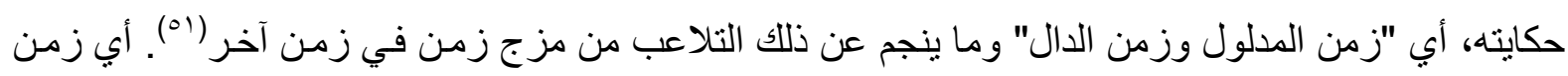
المتن الحكائي بزمن المبنى الحكائي الدال عليه. وتقود هاتـان الملاحظتان إلى ثلاثة ضروب من تحليل الزمن

$$
\text { في النص السردي ودر استه: }
$$

أـالعلاقات بين النظام الزمني لتتابع الأحداث في القصة والنظام الزمني لترتيبها في النص السردي(or). ذلك أن

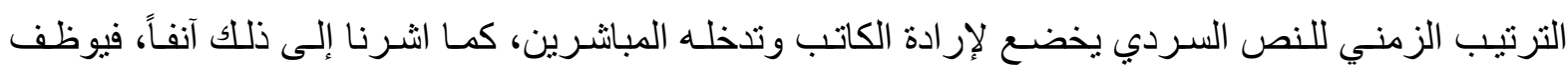
استرجاعات أو استشر افات تُؤمِّن سير الأحداث وربطها، ولتسويغ غايات محددة يكثنف عنها سير السرد وتتابع

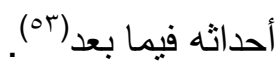

ب-العلاقات بين الديمومة النسبية للأحداث في القصة وديمومة النص السردي أي "طولـه"، وهي علاقة ترتبط بمفهوم النسق(؛ُ). و يتجلى تحليل ديمومة النص القصصي في ضبط العلاقة بين زمن القصة الذي يقاس بالثواني و الدقائق و الساعات والأيام و الثهور و السنوات، وطول النص السردي الذي يُقاس بالجمل و الأسطر و الفقرات 
و الصفحات، وتقود دراسة هذه العلاقة إلى استقصاء سرعة السرد و التغيرات التي تطر أ على نسقه من تعجيل أو تبطئة له، إذ يمكن لأجل ذلك التمييز بين أربعة أنساق هي(00): (المجمل، والحذف، و التوقف، و المشهر)

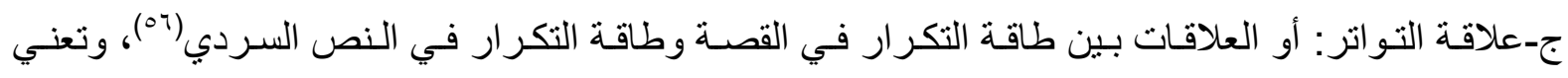

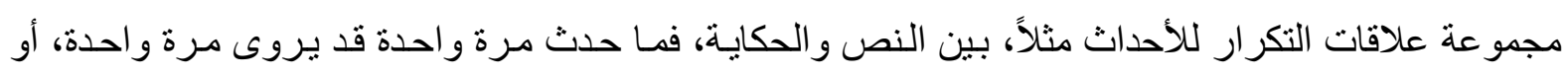
أكثر من مرة، أو أن يروى أكثر من مرة ما حدث أكثر من مرة، أو ما حدث مرة واحدة(

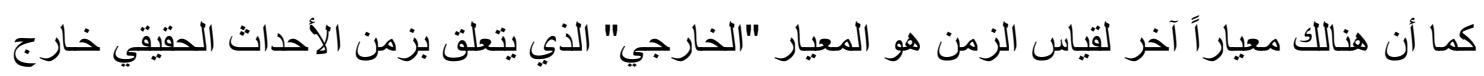

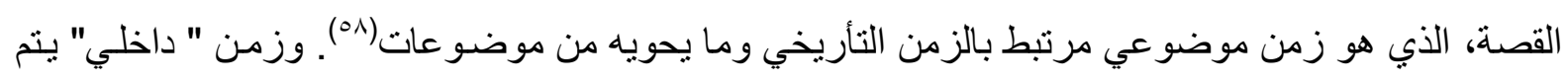

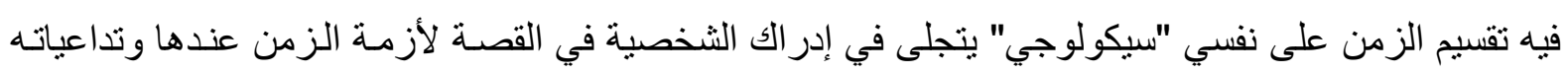

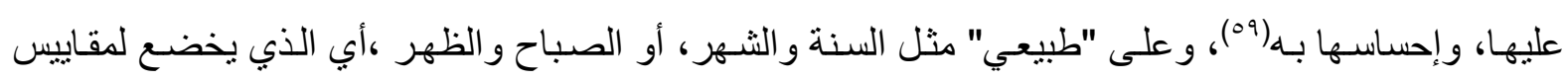
الزمن الطبيعي(.).

وسوف يتم التركيز في دراسة الزمن في نصوص الكاتبات العر اقيات على (الاسترجاع و الاستشر اف) في العلاقات بين النظام الزمني لتتابع الأحداث في القصة و النظام الزمني لترتيبها في النص السردي؛ وذلك من أجل استجلاء محنة الثخصية ومدى تأزمها أو احساسها بالفقد و التشظي في النصوص عينة عينة البحث.

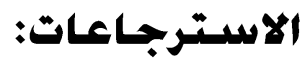

تقنية زمنية تعني سرد أحداث أو أقو ال أو أعمال وقعت في ماضـي الثخصيات، ومعيار ذلك الماضي هو الحاضر الذي يتم فيه السرد الآني لأحداث النص، حيث يترك الراوي مستوى القص الأول ليعود إلى بعض ونض الأحداث الماضية ويرويها("). ربَّما أن هذه التقنية الزمنية لا بدَّ منها في السرديات الحديثة، لأنها تعمل على استدر اك مـا لم يتم سرده من أحداث أو غير هـا، وكذلك تمكنها من رسم عـالم الثخصيات في الماضـي من أجل الإفـادة منه في تكوين صورة عنها في الحاضر، فضلاً عن أن استذكار تفاصيل أحداث ماضية في نقطة محددة من السرد، من شـأنه أن يعمق أثر هذه الأحداث ويمنحها بعداً أكبر. من أجل ذلك وجدنا أن القاصـات العر اقيات تستند في سردهن لعالم شخصياتهن السردي على الماضي المُستذكر باستمر ار، و على مـا تختزنـه ذاكرة الشخصيات من تفاصيل

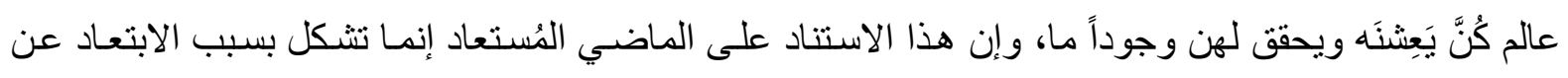

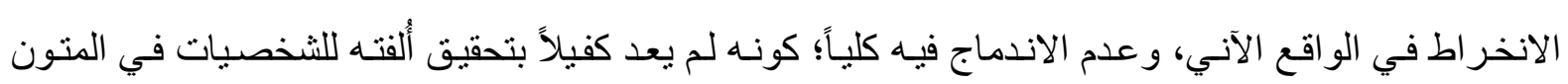

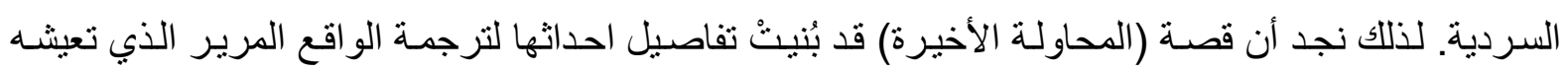
الثخصية التي سقطت في سورة عذابات مستمرة ومتكررة حجَّمت دور ها في الحياة، وقلَّصت آمالها وتطلعاتها حتى غابت في ظلمات البيت وصخب الأسرة. إحساسها بالهم و التلاشي في تزايد، ممـا يستدعي شعور ها بالفقد و التشظي ويعمق احساسها بالوحدة: (وحدة حارقة والبيت يضج بأصو ات صاخبة]...] توقفت أسرتي عن إيجاد حل لما أو غلت الدخول فيه، تكبير ها لم ينغصني والأسى ير افقني وأنا ألد طفلي الرابع، وأنا أحمل طقلي السـادس 
[...] غابة من الأطفال حولي. أرضع معهم سنواتي وأرتشف قطرات بؤسي [...] أتجمد عند نظرة تتكلم عبر صورتي، حروفها تتصت باهتمام إلى همس يناديني بأن بؤسي يأتي عبر حياتي...)(بآل). زاوجت البطلة في هذا الاقتباس من مونولوجها الداخلي بين الأفعال الماضية والافعـال المضـار عة،

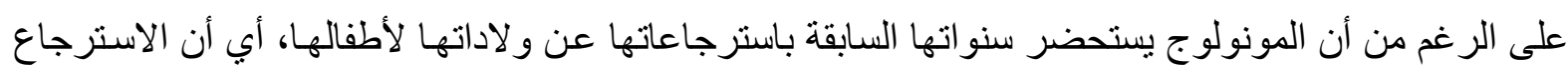
لم يبنى على أفعـال ماضية فقط، بـل استعان بالأفعال المضـار عة أيضـا، مـن أجل أن ثُشـعِر -السـاردة-المتلقي باستمر ار أزمنها إلى زمن السرد الآني، بغية زجَّه في جو القصة بشكل نام، وتفاعله مع محنة الثخصية أيضاً. إن سـر تعاسـة هذه الثخصية يأتيها عبر حياتهـا هذه، فعـاباتها مستمرة وعدد أطفالها يـزداد وهـم يرضـون معها سنوات عمر هـا، بينمـا ترتشف هي قطرات بؤسـها وحزنها، تتأمل ذلك كله في استرجاعاتها لحياتها، لتجد أن تلك الحياة ما هي إلا موت بطيه، فالموت الذي لم تعد تخشـاه يتزين لها، حتى أنها قد ألفته،

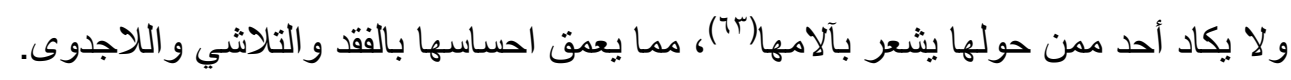
أما قصة (ابتكار سعادة) فقد استعانت بالتبئير الداخلي في سرد استرجاعات الثخصية لحياتها الماضية

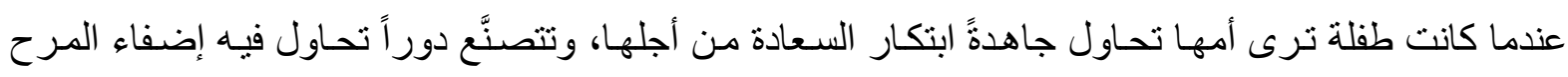
و الفرح على ابنتها، على الرغم من استقر ار الحزن الصامت في داخلها، تجسد ذلك من خـلال حفلة عيد المبلاد التي تجهز ها الأم لهذه الطفلة: (لليس تماما أنني ولدت في مثنل هذا اليوم.. مـا زلت مُصرة على ذلى ذلك...بيد أن أمي لا تنفك تذكرني قبل أسبوع من حفلة "عبد مبلادي" مـاذا تعد، و أي الأسماء تضـعها في قائمـة الدعوة.. أي

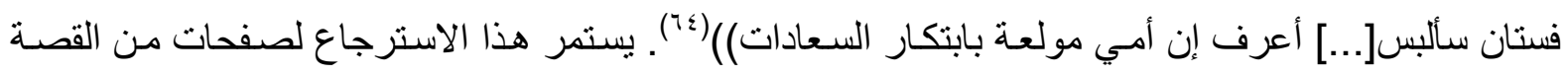

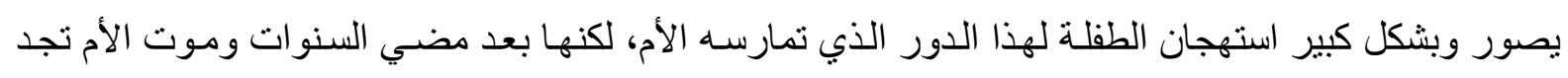
هذه الطفلة، التي أصبحت أُمَاً أيضاً، بأنها قد ورثت هذا الدور عن والدتها. تقول الطفلة/الأم: ((غير أنتي بعد

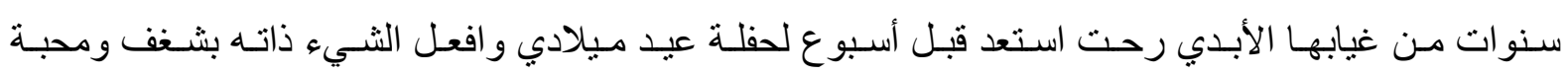
لابنتي)("70).على الرغم من أن أعياد الميلاد تعد من الممارسـات التي تنشـر الفرح و السرور، فضـلاً عن دلالنة كلمة (بشغف ومحبة) التي تضمنها الاقتباس، إلّا أن هذه الاسترجاعات قد تضمنت بعداً ترميزياً للدور النمطي

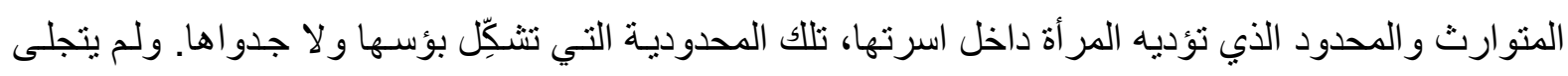

ذلك بالكلمات فقط، بل بالتبئير الداخلي للشخصية الذي أفصحت عنه استرجاعاتها وعمَّقت من إنزو ائها أيضاً. قصة (همس البحر) هي أيضا تسرد على وفق استرجاعات البطلة التي تكون قد فارقت الحياة، ومـا أُثر عنها من سرد ما هو إلا استرجاعات لواقع أليم ومحزن عاثته بضياع وتشظي، تحكيه للروح المأزومـة التي تلتقي بها عند ساحل البحر : ((قبضت بكفها على حفنة رمال تشع بالدفه، تركتها تتث من بين اصسابعها كسـاعة

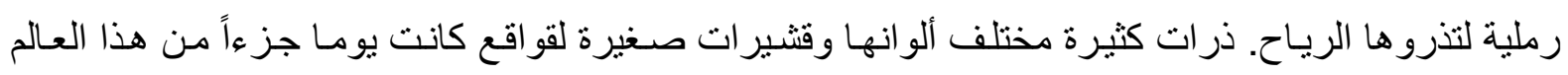

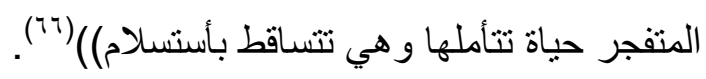
إن هذا الاقتباس لم يلقي بالضوء على تفاصيل حياتها التي كانت قد سردتها لروح الثـاب الذي معها، بل شخَّص بوضوح مدى الانكسار الذي تعانيه هذه الشخصية، إذ إن كل شيء حولها يتلاشى ويسقط باستسلام كائسام 
عمر ها التي أصبحت في مهب الريح يوم كانت جزءاً من هذا العـالم، فتسبر نحو البحر وهي تتأمل ضباعها وتلاشي أثر ها لتظل مجرد ذكرى ماكثة في عقلها تهمس بها لأمو اج البحر : (سـارت باتجاه البحر... خطواتها

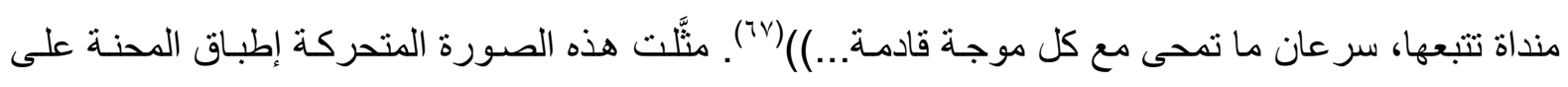
الثخصية بشكل تام، ورسمت نلاشيها و إحساسها بالفقد. ومثلها تماماً كانت قصة (غنيان) التي يأتينا السرد فيها من خلال الشخصية الميتة أيضاًّ(^). و لا بد في هذا المقام من تأكيد سمة فنية تتجلى في الاسترجاعات و لا تتحقق لغير هـا اطلاقاً، تتحدد هذه السمة في قدرة الاسترجاعات على دمج زمن في زمن آخر، فهي بطبيعتها تكون تلخيصاً لحياة طويلـة للثخصية

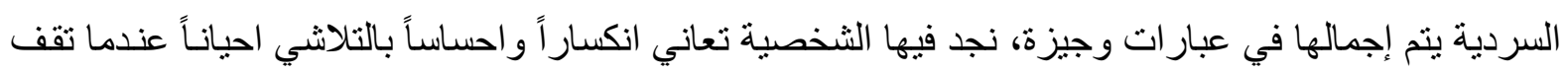
و هي تتأمل حياتها الماضية، وهذه السمة تحقق جمالية لفن القصـة القصيرة ومنفعة للقارئ أيضـاً، تتجلى السمة الجمالية في قدرتها على تغيير خط سير السرد، وكسر نمطيته، عندما لا يكون هنالك رتابـة في سرد الاحداث،

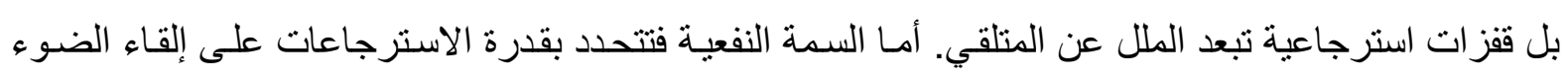
على ماضي الشخصيات، أو تفاصيل الاحداث و أبعادها، مما يمكِن من ردم الكثير من الفجوات التي من المككن أن تظهر في مجرى السرد أو في رسم الثخصيات أمام عيني القارئ. كل ذلك يحقق أهمية الاسترجاعات في مئري فن القصـة وضـرورتها أيضـاً، فضـلاً عمَّا تنَّ التطرق إليـه في هذا المبحث من قدرة هذه التقنيـة على استكناه الأغوار النفسية للشخصيات وكثف خو افيها وتأزمها.

\section{الاعستشغرافات:}

هي تقنية تأتي على الضد تماما من تقنية الاستذكار، ويُر اد بها التنبؤ بوقوع أحداث مستقبلية سيثـهدها

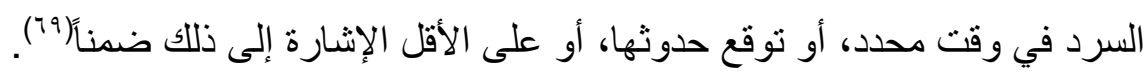

هذا النمط من السرد يقضـي بقلب الأحداث في النص السردي عن طريق تقديم منو اليات حكائية محل أخرى سابقة عليها في الحدوث؛ أي القفز على نقطة ما من زمن القصة كان قد وصل إليها السرد، لاستشر اف

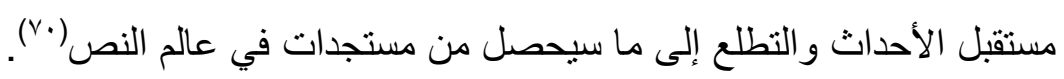

وربما يكون السرد بضمير الـ(أنا) هو الأسلوب السردي الأنسب الذي يتم من خلاله تذويب استشر افات مستقبلية بشكل مضمن غير مقحم، غير أن لتقنية الحلم في النصوص السردية أهمية كبيرة في الإشـارة إلى الى الى

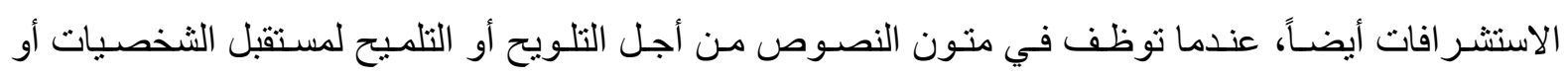
أحداثها المقبلة. ففي قصة (صروح) مثلاً جاء الاستشر اف على شكل حُلُم للثخصية البطلة، كمـا ان تفسيره من قبل و الدة الفتاة قد أزال عنه كل ترميز أو تشفير، وبذلك يتجلى الاستشر اف بشكل لخَّص حياة البطلة المستقبلية

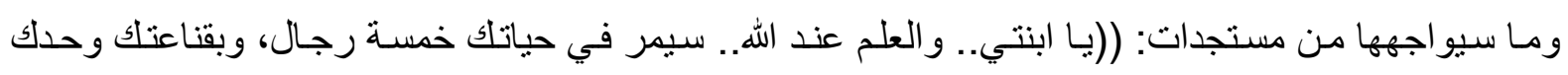
ستكونين الطرف الحاسم للقضية، وأنت دائماً من يقلع نبتة الحب التي تتمو بينك وبينهم[...] وستغيرين مكانك بعدها وسيكون التغير نحو حياة جديدة وحب جديد في أرض جديدة))('(V). يستجلي هذا الاقتباس محنـة الثخصية التي تعيش على أمل تحقيق حلمها الوردي، وتترك الواقع يسير على وفق ذلك الحلم، مما يؤكد عفويتها وضعفها 
عن خلق مستقبلها، مثل ريشة في مهب الريح. كمـا أن الأفعال المضـار عة السـابقة الدّالة على الاستقبال، بدلالة "سين الاستقبال" قد ألقت الضـوء بشكل واضـح وشديد السـرعة على مستقبل القتـاة، إذ لم يعد ذلك المستقبل

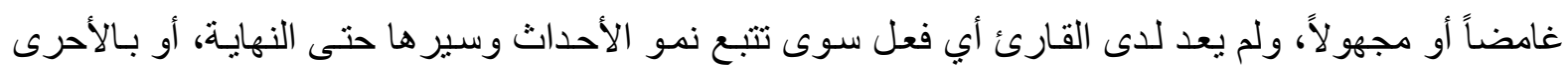

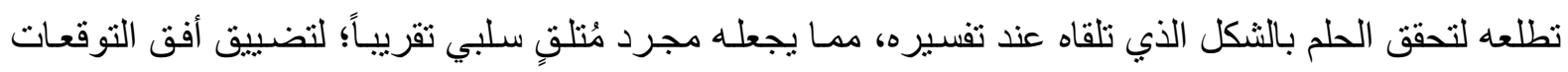
لديه، عند قصر التحليل على ما نَّ توقعه من قبل والدة البطلة.

غير أن ذلك الاستشر اف قد عمل على تحقيق أمور مهمة على الرغم من إخفاقه في تفعيل دور القارئ، فقد ساعد على خلق عنصر التشويق لديه عند حثه على تتبع السرد، وإعداده لمـا سيتم سرده عليه من أحداث، فضلاً عن تمكنه، وبدرجة كبيرة، من ربط أجزاء المتن الحكائي بعضهـا ببعض، وتحصين النص ضد التفكلك

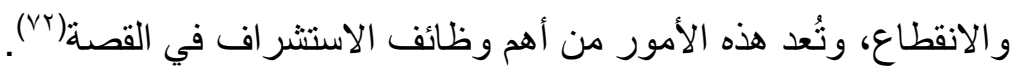

وتعد الثخصية الرئيسة في قصـة (لم أعد أحلم) هي الأخرى أكثر تمسكاً بعيثها في الاحلام، وتركها الو اقع تماماً غير عابئةً به إطلاقاً، إذ إن القصة بمجملها تسرد على شكل حلم متكرر ير اود البطلة في منامها وحتى في يقظتها، عندما نظل تستذكر تفاصيله، وهذا الحم هو استتر اف لماستكون عليه الأمور تقريباً في لاحق السرد: ((الثـاحنة التي تحمل حزم الأسياخ جـاءت مسرعة واخترقت البـاص الذي اجلس فيه، فدخلت

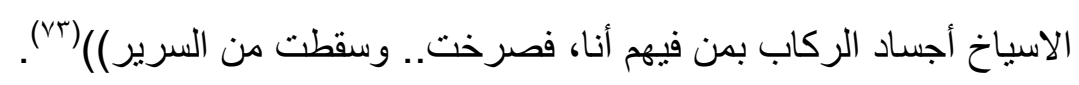

تخبر البطلة جدتها بالحلم وهي تغزل الصوف بيديها، فتخبر ها الأخيرة، غير مبالية بـالحلم، بأنها أضـغاث

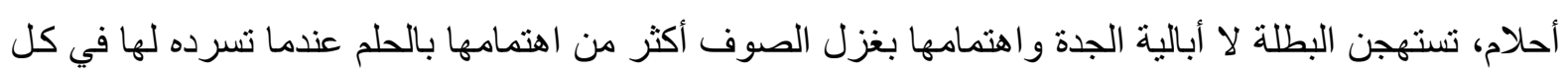

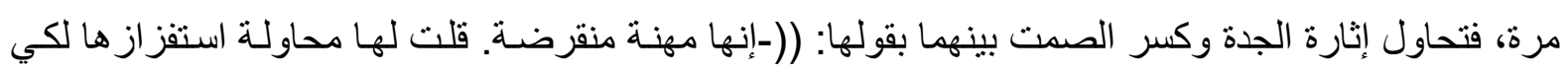

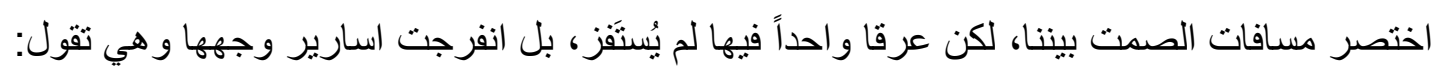

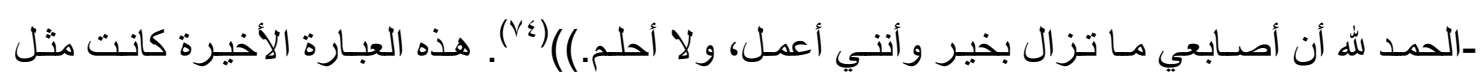
الصاعقة التي ضربت البطلة و أثارت اهتمامها، فالجدة هنا سخرت من وضعها الحالم ومن سلبيتها، ممـا جعلها تلوذ بالصمت لتتأمل انكسار ها وانهز امها، فيما تذهب الجدة للسوق دون عودة، إذ قيل إن شـاحنة محملة بأسباخ الحديد جاءت مسرعة واخترقت الباص الذي تجلس فيه، فدخلت الاسياخ في أجساد الركاب بمن فيهم الجدة(V0.). هذا النوع من الاستشر اف يختلف عمَّا تناولناه في المثال الأول، إذ إنه جاء على افعال ماضية ولم يبنى

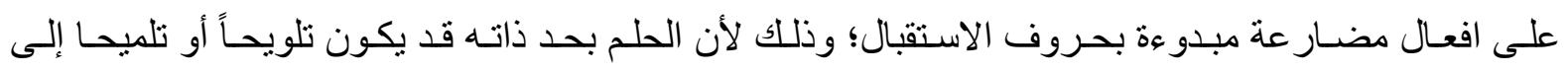
استتر اف أمور ستتحقق في المستقبل، ولكن عند سرده حتمـاً سيُسرَد بأفعال ماضية، وبذلك يمكنتـا أن نقول أن الاستشر افات في المتون السردية لا تتحصر بالافعال المضار عة المسبوقة بحروف الاستقبال، وكما تم إيضـاحه. هذه من جانب، ومن جانب آخر فإن هذا الاستشر اف يقوم على غموض ما، يجعل من أمر انكثـافه بشكل كامل بحسب توقع القارئ له غير متحقق، مما يثير اهتمام القارئ ويحفز تفكيره- نو عا ما- للتأويل والتأمل. 
ويبدو أن الاستشر اف لم يكن له ذلك الحضور الذي حظي به الاسترجاع، مما يؤكد تأزم الثخصيات في قصص القاصات العر اقيات، إذ إن تلك الثخصبات مـا زِلنَ في توق للماضـي الذي يحقق لهن الألفة و الراحة أكثر من الحاضر الذي يمارس عليهن سطوته، ويثـعر هن بانكسار هن، فيتركهن يعشن بحزن وبإحسـاس بالققد

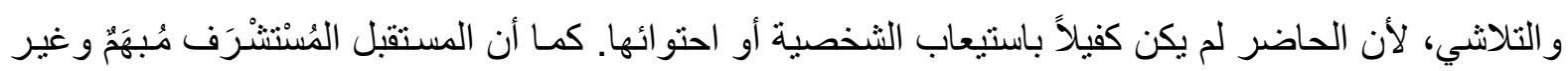
و اضحٍ، وليس هناللك قدرة للثخصيات على التطلع إليه؛ لانغمار ها في انكسار اتها وتتظيها. من هنـا يبرز مـا للزمن دور فاعل ومؤثر في تجسيد الحالـة النفسية للشخصيات وتصسوير الإحسـاس بالضيق و الانكسار الذي يرسم قلقها واضطر ابها، وبالتالي تشظيها في عالمها المعيش، مما دفع المبدعة العر اقيـة إلى تكثيف الزمن في المتون السردية من أجل منح الأبعاد النفسية للشخصيات عمقاً أوضح.

\section{|الخايتم:ت-}

تجسدت مشاعر الحزن والاحساس بالفقد والتلاشي في أكثر قصص القاصات العر اقيات، وقد تحقق ذلك بسبب إحساس الثخصيات بعزلة روحية طاغية على حياتها التي تعيشها، فتتركها ر افضـة لو اقعها أو لمجتمعها

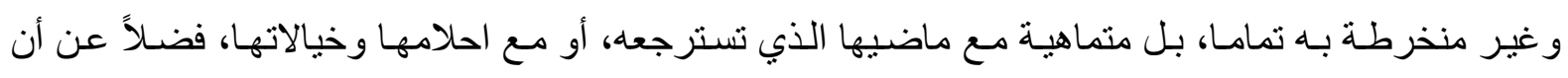
شفافية تلك الثخصيات ور هافة احاسيسها تجعلها أكثر تحساً لسلبيات هذا الواقع المرير الذي يمارس اقصـاءها

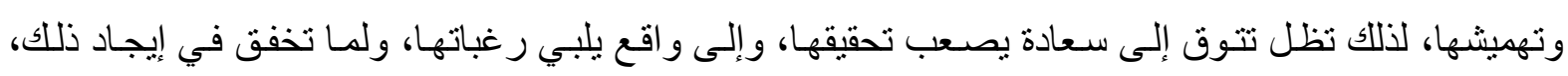
تصل في نهاية المطاف إلى إحساسها بالتشظي و الفقد.

حاولت القاصـات العر اقيـات في المجمو عـات القصصية عينـة البحث نقل التجربـة الذاتيـة بعد تعميق معناها، من مستواها الثخصي إلى مستوى أكبر هو المستوى الإنسـاني الجوهري العـام؛ أب جعل المسـألة أنببه

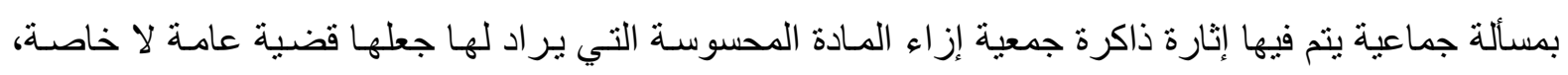
وقد ساعدها في ذلك كله بعض التقنيات التي تم توظيفها في النصـوص السردية للقصـة القصيرة، التي كان من لن أهمها المعادل الموضو عي وقدرته على تمثيل كل ذلك أروع تمثيلٍ.

الهوامش:-

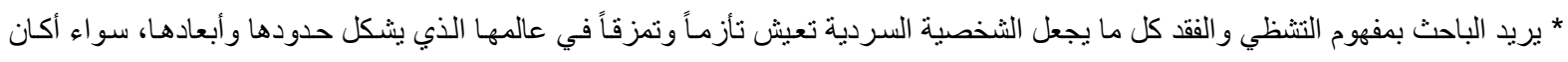

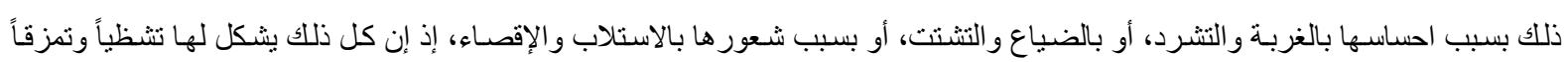

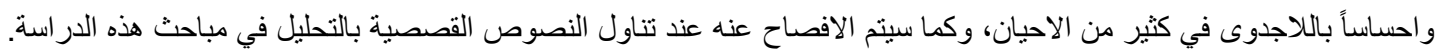

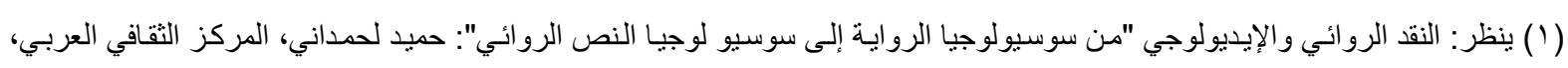

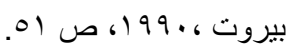
(ץ) ينظر : الرواية السياسية "دراسة نقاية في الرواية السياسية العربية" أحمد محمد عطية، مكتبة مدبولي-نانشرون-القاهرة، مؤسسة مطابع معتوق،

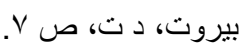

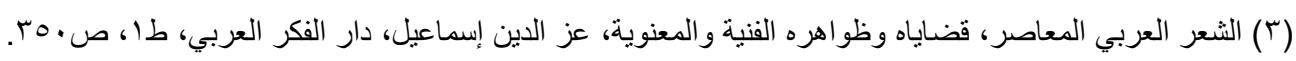

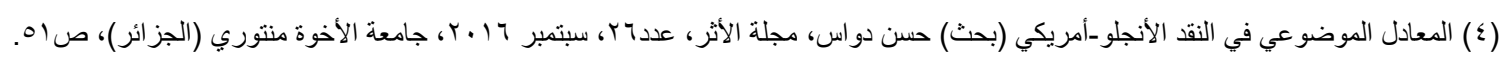
(॰)The sacred wood, Essays on Poetry, T.s.Eliot, London $194 \cdot$ • P 9 r.

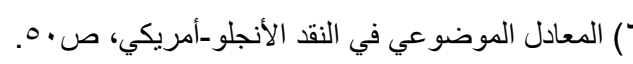




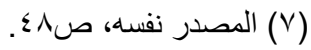

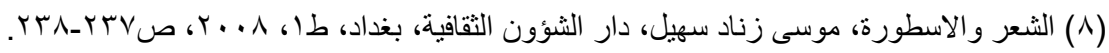

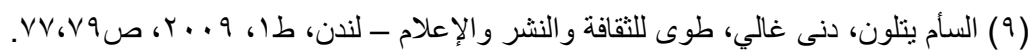

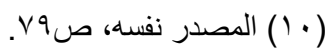

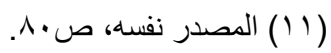

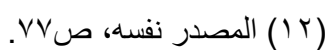

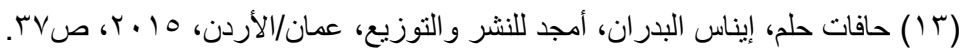

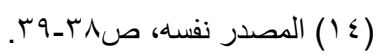

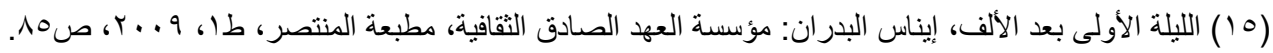

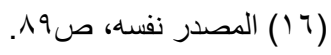

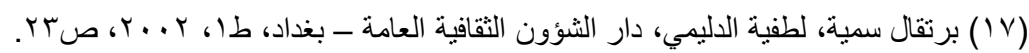

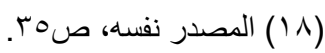

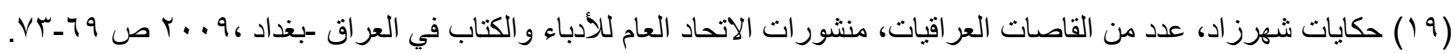

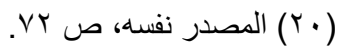

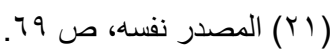

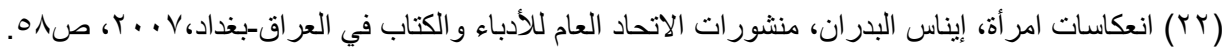

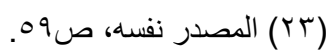

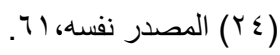

(ro) يُنظر: المصطلح السردي، جير الد برنس، نرجمة: عابد خزندار، المشروع القومي للترجمة، المجلس الأعلى للثقافة، الهيئة العامـة لشؤون

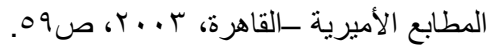

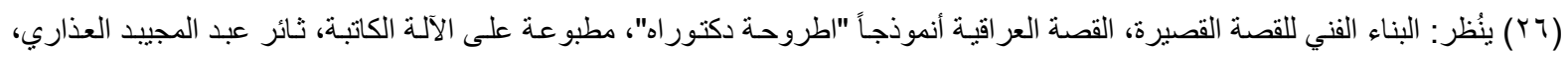

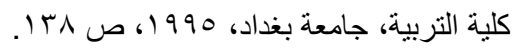

(YV)

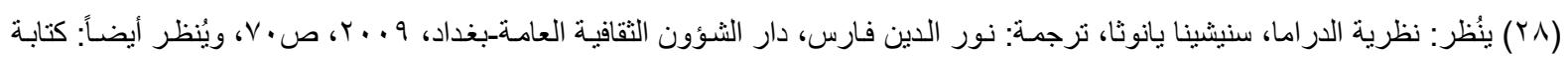

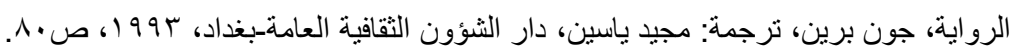

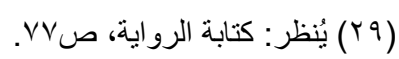

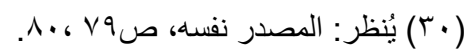

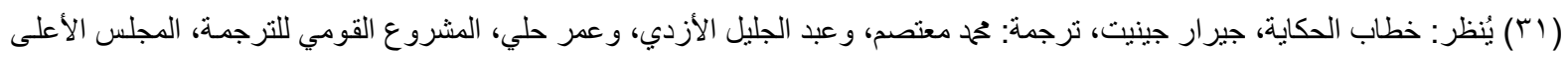

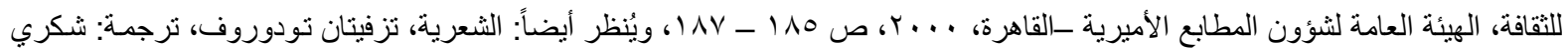

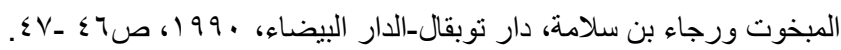

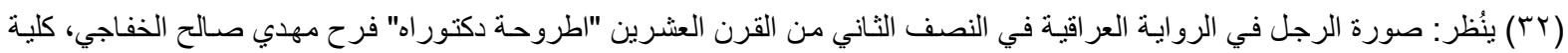

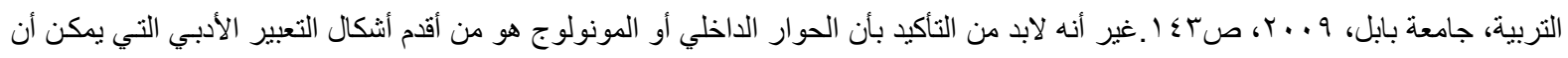
نجد أمثلة له في آداب الحضار ات القديمة المختلفة، وكان يسمى (Prsopopoela) ويمارس في المدارس إتبّاعاً لتعاليم كوينتاليان (Quintalian) وذللك للاعتقاد بأهميته في تدريب الخطباء، وقد تم توظيفه حديثاكثتقنية من تقنيات رواية تبار الوعي، ويعد الكاتب الفرنسي (إدوارد دي جاردن) مخترع "المونولوج الداخلي". غير أنه قد يُنظر، في بعض الأحبان للمونولوج بأنه تفريغ لتيار الوعي "Stream of consciousness"لثخصية ونية ما ويكثر الخط بينهما، ولكن هنالك فرق بين الاثنين في أن المونولوج الداخلي يتعرض لأفكار الثخصية ولا يمس انطباعاتها وتصور اتها التي

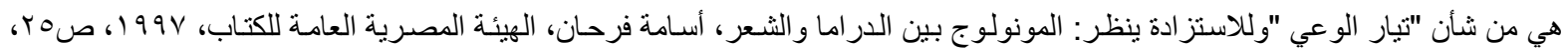

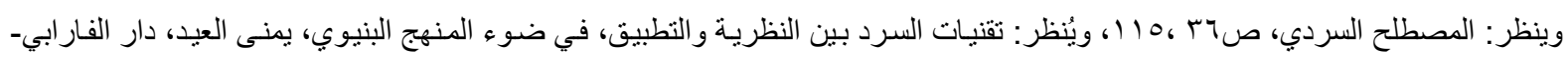

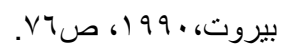

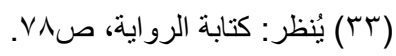




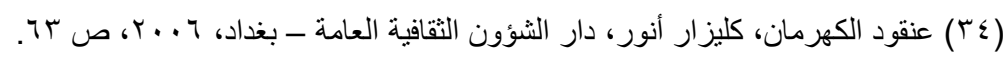

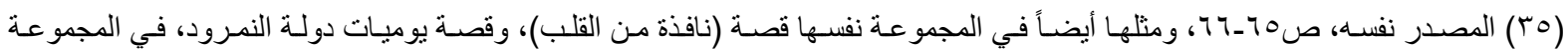

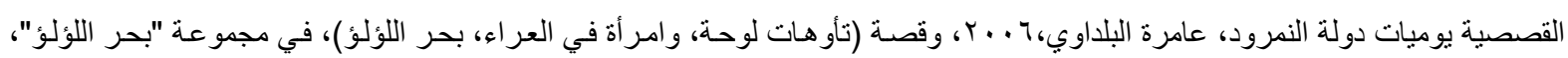

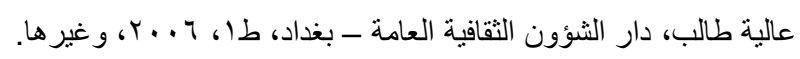

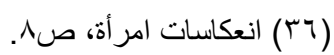

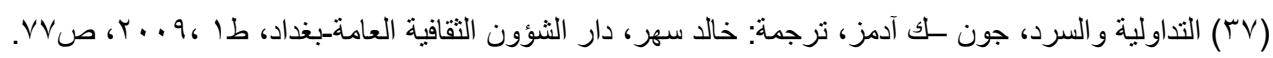

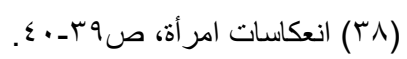

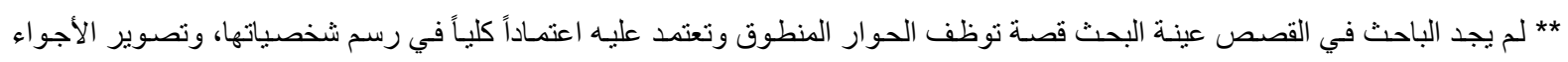
المحيطة، وإلقاء الضوء على الأحداث التاريخية في المدة ما بعد | . . بسوى هذه القصة، وقصة (يوميات دولة النمرود)، في مجموعة "يوميات دولة النمرود"، إذ كان الحوار المنطوق يؤازر الأنواع الأخرى من الحوار في النصوص القصى القصية القصيرة للقاصات العراقيات.

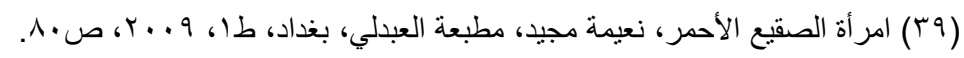

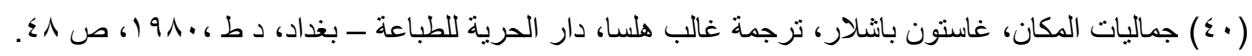

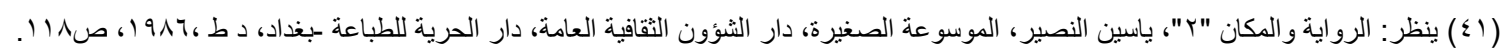

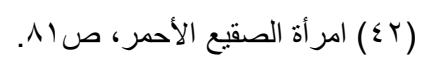

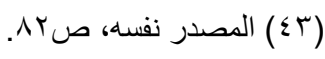

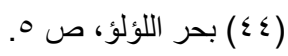

(0) من القصص التي سـارت على "المونولوج" قصـة (امر أة الصقيع الأحمر ،و الغرير، و والمد والجزر،...) في المجموعة القصصية، امر أة

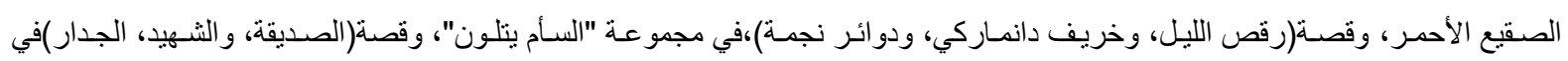

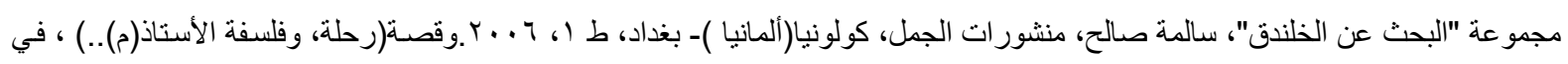

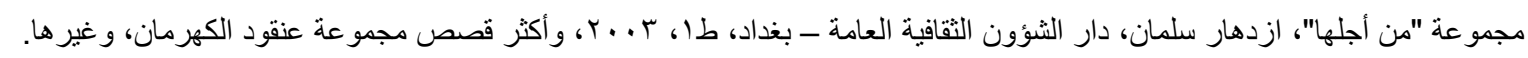

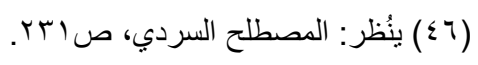

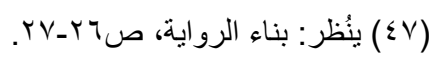

( ) (§^)

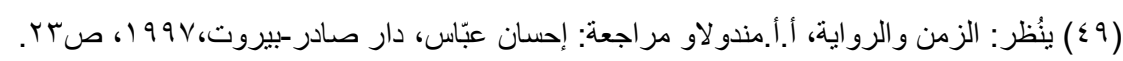

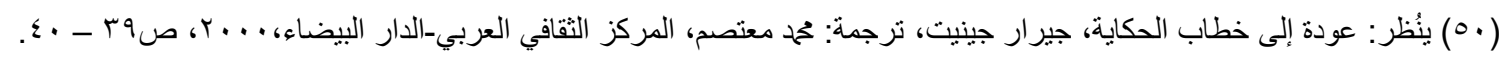
(0)

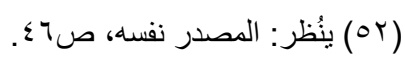

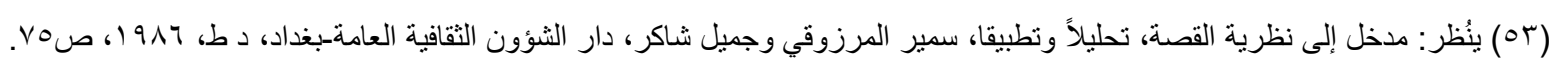

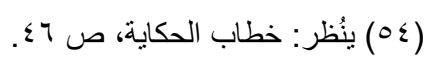

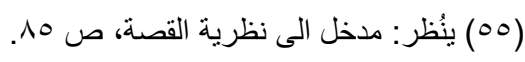

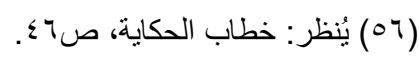

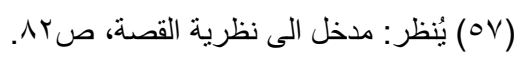

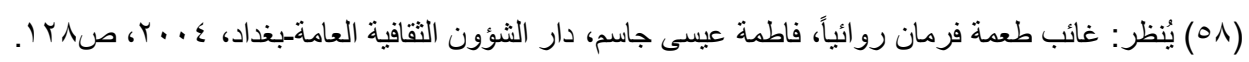

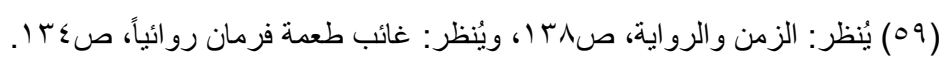

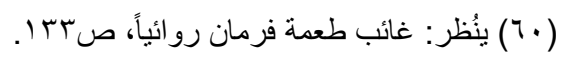

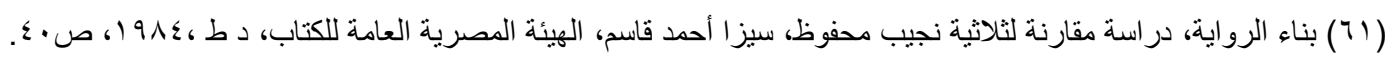

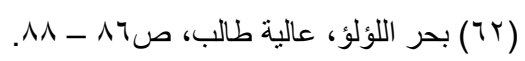

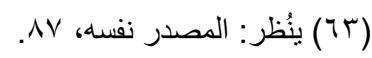

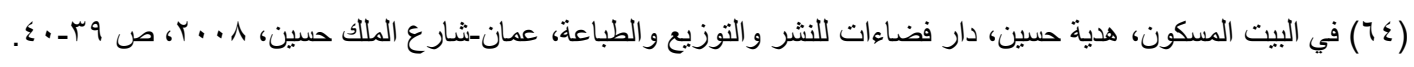

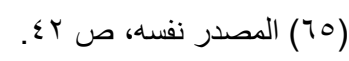




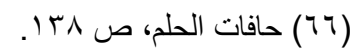

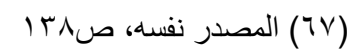

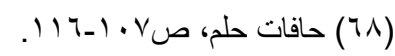

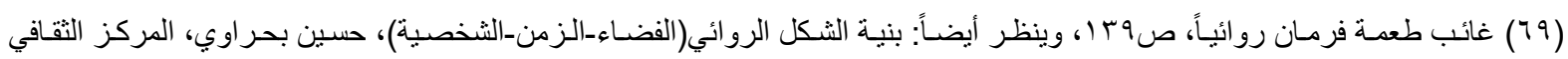

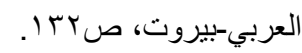

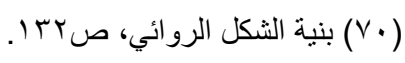

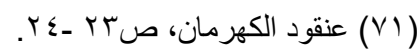

(VY)

( )

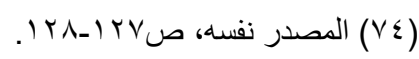

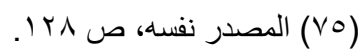

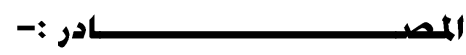

أولاً: المجاميع القصصية: - المال

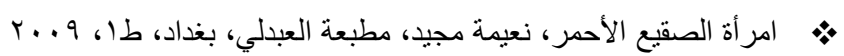

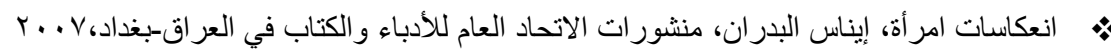

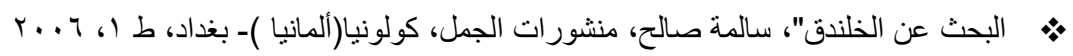

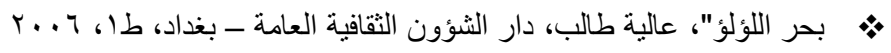

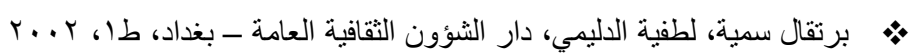

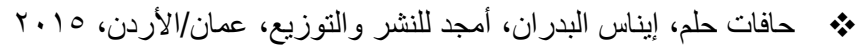

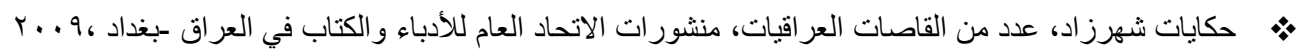

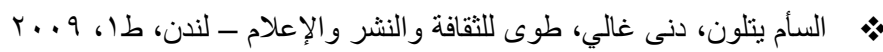

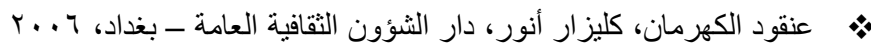

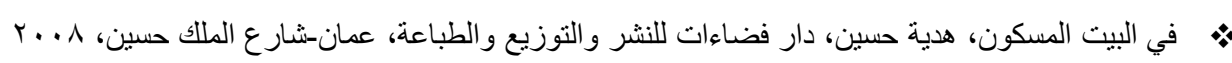

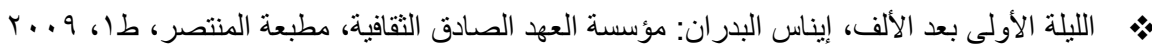

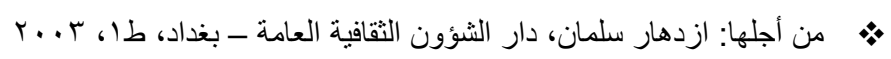

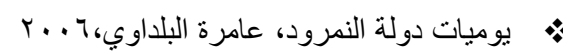

ثانياً: المصادر والمراجع العربية و المترجم إليها:

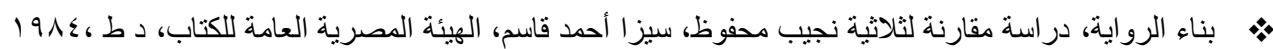

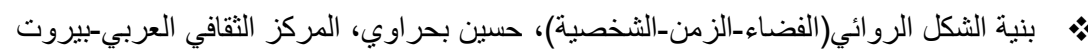

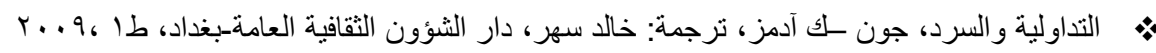

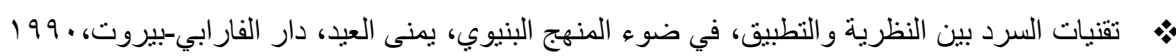

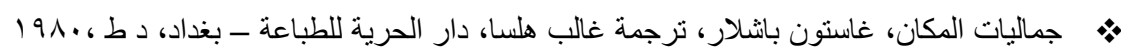

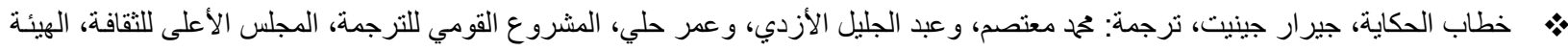

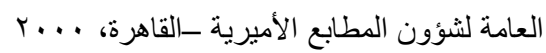

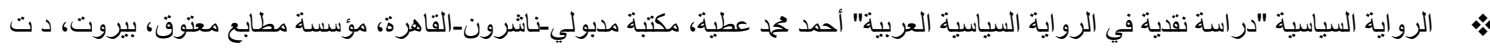

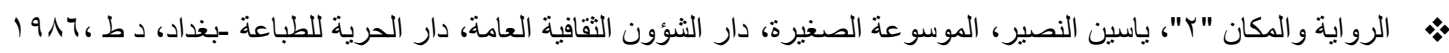

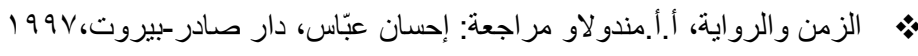

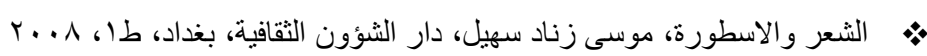

•

• الثعر العربي المعاصر، قضاياه وظواهره الفنية والمعنوية، عز الدين إسماعيل، دار الفكر العربي، طأ. 


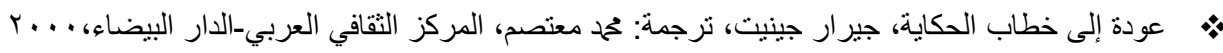

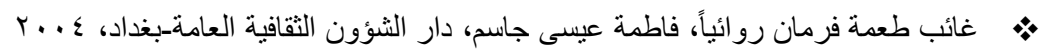

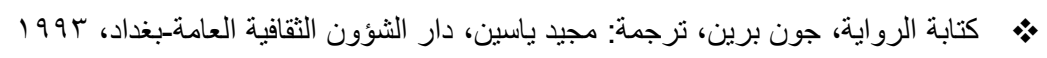

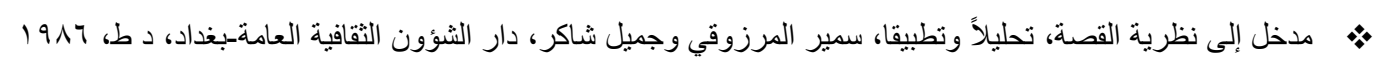

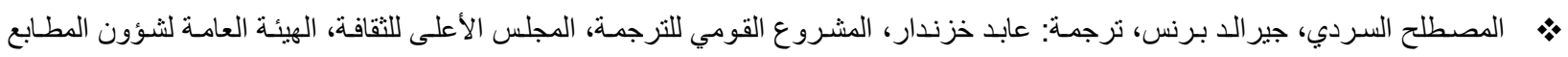

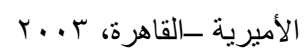

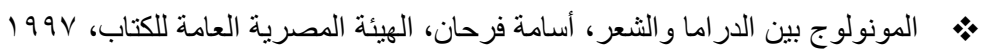

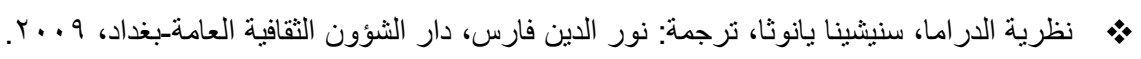

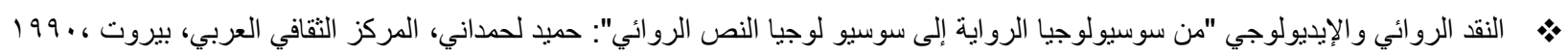

ثالثاً : المصادر الإنجليزية :- الزئ

-The sacred wood, Essays on Poetry, T.s.Eliot, London $194 \cdot, \mathrm{P} 9 \mathrm{r}$.

رابعاً: الأطاريح والرسائل والبحوث الجامعية:

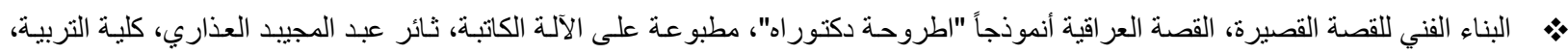

جامعة بغداد، 1990

هـ صورة الرجل في الرواية العر اقية في النصف الثاني من القرن العشرين "اطروحسة دكتور اه" فرح مهدي صـالح الخفاجي، كلية التربية، جامعة

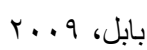

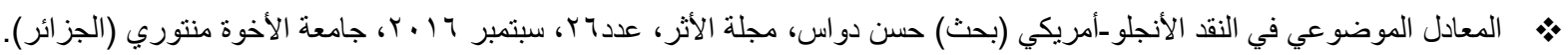

